\title{
Review: Groundwater management and groundwater/surface-water interaction in the context of South African water policy
}

\section{Jonathan Levy • Yongxin Xu}

\begin{abstract}
Groundwater/surface-water interaction is receiving increasing focus in Africa due to its importance to ecologic systems and sustainability. In South Africa's 1998 National Water Act (NWA), water-use licenses, including groundwater, are granted only after defining the Reserve, the amount of water needed to supply basic human needs and preserve some ecological integrity. Accurate quantification of groundwater contributions to ecosystems for successful implementation of the NWA proves challenging; many of South Africa's aquifers are in heterogeneous and anisotropic fractured-rock settings. This paper reviews the current conceptualizations and investigative approaches regarding groundwater/surface-water interactions in the context of South African policies. Some selected pitfall experiences are emphasized. The most common approach in South Africa is estimation of average annual fluxes at the scale of fourth-order catchments $\left(\sim 500 \mathrm{~km}^{2}\right)$ with base flow separation techniques and then subtracting the groundwater discharge rate from the recharge rate. This approach might be a good start, but it ignores spatial and temporal variability, potentially missing local impacts associated with production-well placement. As South Africa's NWA has already been emulated in many countries including Zambia, Zimbabwe and Kenya, the successes and failures of the South African experience dealing with the groundwater/surface-water interaction will be analyzed to guide future policy directions.
\end{abstract}

Keywords Review. Groundwater/surface-water relations. South Africa. Groundwater management. Socio-economic aspects

\section{Introduction}

In 1994, South Africa began a new era with its first democratically elected government and an end to the apartheid regime. Legal changes were enshrined in the new constitution of 1996, providing the basis for many new policies and laws that targeted the eradication of poverty and the building of race and gender equality (Schreiner and van Koppen 2003). Water policy was no exception to these sweeping corrective actions. The South African National Water Act (NWA) of 1998 recognized water as a basic human need and its importance for ecological sustainability, but it also recognized its role in economics and poverty alleviation and its power as a social tool. Although late in coming to this approach, the 1994 revolution gave South Africa the opportunity to develop such far-reaching water legislation from the top down. With its emphasis on sustainability, social equity and integrated water-resource management, the NWA is widely regarded as one of the most progressive and enabling pieces of water legislation in the world (van Wyk et al. 2006; Seward 2010). The troubling question remains, however, whether 
such ambitious legislation can be realistically implemented. This question is important to more than just South Africans. The NWA has been touted as an example for other counties to follow and has been adopted in various forms in Zambia, Zimbabwe and Kenya. Countries throughout Africa and the world will be analyzing the successes and failures of the South African NWA to guide their future policy directions.

More than a decade has passed since the NWA was promulgated, but there are many factors that contribute to the challenge of successful implementation of the NWA, including misunderstanding of the underlying principles and overcoming the legacy of inequality and disproportionate government representation and participation. Challenges to successful implementation also include scientific uncertainty. To sustainably develop water resources, it is necessary to ascertain how much water is present and how much can be sustainably allocated without jeopardizing ecosystems and the interests of downstream users. Estimating groundwater volumes and fluxes for ground- water development poses a particularly difficult challenge in South Africa due to the widespread occurrence of fractured-rock aquifers. Sustainable groundwater development depends partly on determining the potential impact of that development on the groundwater contribution to rivers, lakes, wetlands and estuaries. Such surface-water/groundwater interactions are among the most important aspects in the protection of valuable aquatic ecosystems and therefore in land-use planning. Many direct and indirect methods are available for investigating, characterizing and quantifying groundwater/surface-water interactions. Some of these are small-scale methods including use of minipiez- ometers and seepage meters. Methods applied at a larger scale, more appropriate for meeting policy needs, include baseflow separation, hydrogeologic mapping, vegetation mapping and ecoregion classification, groundwater modeling, hydrochemical analyses and stable-isotope analyses. Quantifying groundwater/surface-water interactions is always difficult, but it is especially complex in the South African context where so much of the usable groundwater flows through fractured-rock aquifers.

This paper reviews past research on conceptualization and quantification of the groundwater contribution to surface-water bodies and flows in the context of South African water policy and hydrogeologic setting. The South African policies that require such quantification are summarized and placed in their historic context. Also summarized are the variety of quantification approaches and tools that have been employed in this endeavor. The question is addressed of whether in fact the science of investigating surface-water/groundwater interactions is ready for the much-desired implementation of the progressive South African water policy. 


\section{Overview of South African climate and geology}

Groundwater/surface-water interactions are complex with spatial and temporal heterogeneities and being affected by a multitude of factors. The interactions are governed by the geometries and relative positions of surface-water bodies and aquifers as well as by human influences including land use and the control of water (channelization, building dams and levees, etc.). Perhaps the most crucial is the influence of climate and geology. An overview of these factors in South Africa is therefore presented here.

\section{Climate}

Climate is the main regulator of the water-table depth and surface-water stage, so it is also a main driving force for interactions that depend on the hydraulic-head difference between surface water and groundwater. As a result of a varied topography and oceanic influence, a great variety of climatic zones exist in South Africa. In the far northwest, there is a desert climate influenced by the Kalahari and southern Namib. Mean annual precipitation in this region is as low as $29 \mathrm{~mm}$ (Fig. 1; Le Maitre and Colvin 2008). Much of the country's western interior is dominated by the Karoo plateau (Fig. 1) with a semi-arid climate (100-400 $\mathrm{mm} /$ year) and semi-desert vegetation (Schulze et al. 1997). The mean annual precipitation rates of the Karoo range from about 100 to $250 \mathrm{~mm}$. Heading east from the Karoo, rainfall generally increases as the climate transitions to that of the Highveld (Fig. 1) with mean annual precipitation rates of $250-750 \mathrm{~mm}$ and vegetation ranging from steppe, bush-grass savanna to grassland. Precipitation continues to increase to the east where the climate eventually becomes humid subtropical and even humid tropical along the northeast coast with mean annual precipitation rates of $750-1,900 \mathrm{~mm}$ and the vegetation transitions to montane forest and East African coastal forest. Temperatures do not increase much from south to north in most of the interior due to the higher elevations of the Karoo and Highveld. Temperatures do vary considerably from west to east. Along the west coast, temperatures are kept cool by the Benguela current flowing northward along the Atlantic Ocean coastline. In the east, temperatures are about $6^{\circ} \mathrm{C}$ warmer than in comparable latitudes on the Atlantic Ocean due to the influence of the Agulhas ocean current flowing southward along the Indian Ocean coastline in the east for several months of the year (SA-Venues.com 2001). Precipitation rates are also high in the extreme southwest cape area where the climate is Mediterranean (Fig. 1).

The timing of precipitation also varies across South Africa. In the humid subtropical region and humid tropical regions in the east, most of the precipitation occurs in the late spring and summer months of November through January (Schulze et al. 1997). To the west, in the Karoo and Highveld, most of the precipitation occurs in late summer and early autumn. Conversely, in the Mediterranean climate of the southwest cape area and along the western Atlantic coast, precipitation occurs mainly in the winter, and along the southern coast, precipitation occurs all year long (Schulze et al. 1997). Le Maitre and Colvin (2008) determined that there was a weak relationship $(\mathrm{r}=-\mathrm{-} .26)$ in which the greater the precipitation rate, the less the month- to-month variability of precipitation. In other words, arid and semi-arid climates tend to have more episodic precipitation. The variability of baseflow and total streamflow was more strongly 
correlated with total rainfall ( $\mathrm{r}=-0.72$ and -0.68 , respectively). The episodic nature of the precipitation also results in a relative decrease in groundwater discharge. For 1,946 fourth-order catchments $\left(\sim 500 \mathrm{~km}^{2}\right)$, there was a strong correlation $(\mathrm{r}=0.78)$ between the precipitation rate and the proportion of streamflow that emanates from groundwater (the baseflow index).

\section{South African aquifer systems}

South Africa occupies the most southern part of the African continent. It is a relatively dry country that is prone to droughts receiving, on average, about $500 \mathrm{~mm} /$ year of precipitation (Woodford et al. 2005). Groundwater constitutes only about $15 \%$ of the total water consumption, yet $65 \%$ of the population is dependent on it. Aquifers in South Africa can be grouped into six principal types based on lithologies and flow characteristics (Le Maitre and Colvin 2008). The most predominant of these is the fractured sedimentary rock, covering $54.6 \%$ of the land area in South Africa, Swaziland and Lesotho and dominated by the Karoo Supergroup (Fig. 1). The second largest aquifer type comprises unconsolidated deposits covering $17.5 \%$ of the land area. Unconsolidated aquifers are found in the interior, especially in the Kalahari basin as well as marine and aeolian deposits along the southwest and northeast coasts. The basement complex and younger granites, extrusive igneous rocks, Karoo dykes and sills, and carbonates cover 11.9, 8.7, 4.6 and 2.7\% of the land area, respectively (Fig. 1). The most productive of these aquifers are the carbonate systems with large solution cavities, the Table Mountain fractured sedimentary subgroup and the primary, unconsolidated coastal aquifers. Le Maitre and Colvin (2008) characterized the general nature of groundwater discharge to rivers for each of the major aquifer types. Groundwater flow through the basement complex and granites, extrusives and fractured sedimentary rocks is mainly through secondary porosity formed through weathering, faults and fractures. Ground- water discharge from these aquifers to rivers is generally limited to discrete locations associated with major faults or fractures. In the case of sedimentary aquifers, the discharge areas may be more extensive and associated with linear contact zones between sandstones and interbedded shale layers or underlying less permeable formations, and the discharge rates may be greater than in other aquifer types due to the sometimes greater permeability. In the Karoo dykes and sills aquifers, discharge usually occurs in limited quantities in springs, seeps or wetlands. In unconsolidated deposits, groundwater discharge is more diffuse and occurs when river levels drop below the water table between high flows or floods. 


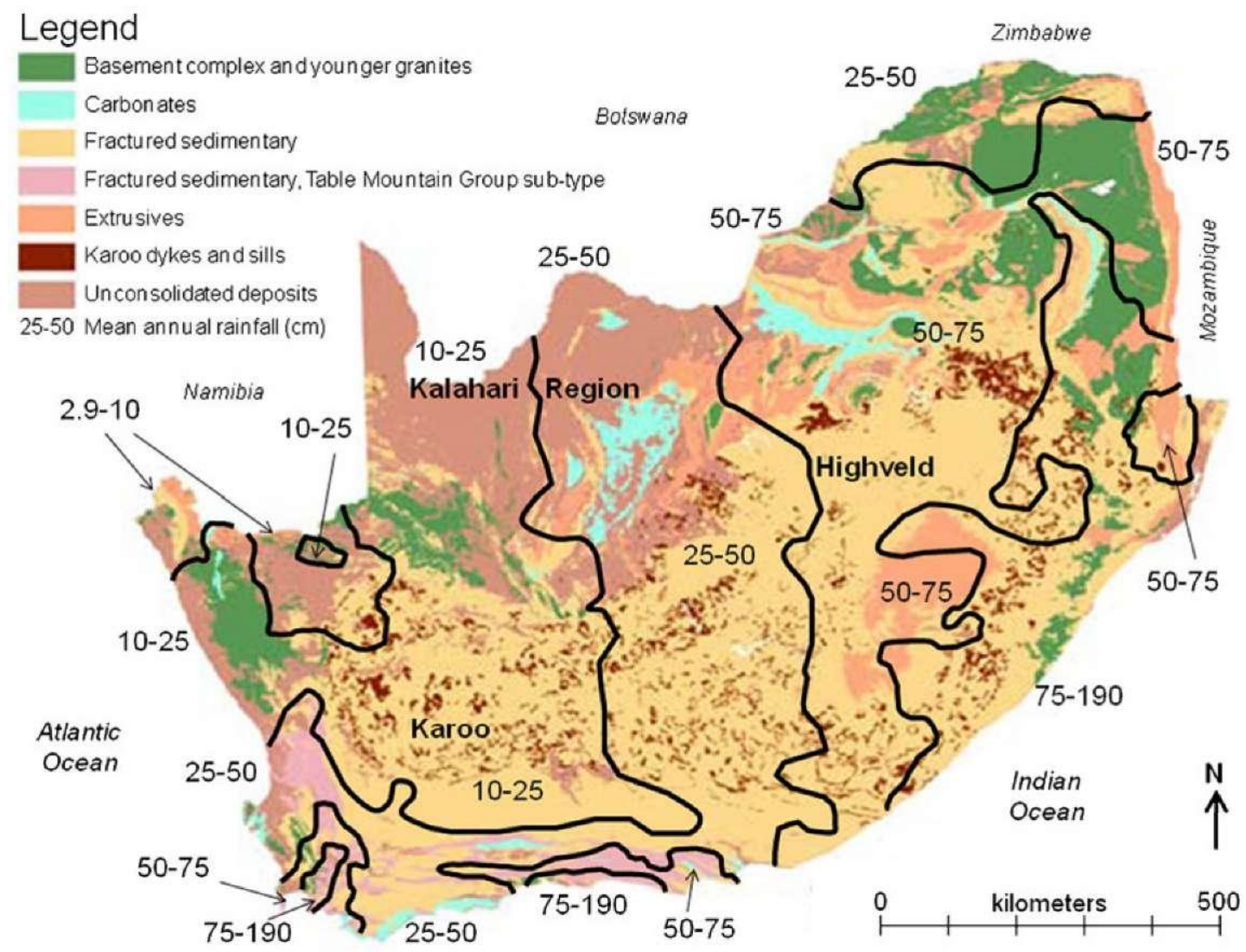

Fig. 1 Principal aquifer types and generalized mean annual precipitation (in $\mathrm{cm}$ ) in South Africa, Lesotho and Swaziland (adapted from Le Maitre and Colvin 2008; Midgley et al. 1994)

\section{South African water policy Redressing past inequalities}

Funke et al. (2007) provide an excellent review of the evolution of South African water policy, and a summary is provided here to provide context for evaluation of future policy regarding groundwater/surface-water interaction. Funke et al. (2007) report that South Africa has a long history of inequitable water policy beginning in the seventeenth century when the Dutch East India Company took strict control of water and land in the Western Cape, limiting the access to water by the indigenous Khosian tribes of the Khoikhoi and the San. In 1685, the Dutch East India Company granted land ownership and the associated riparian water rights to Dutch settlers. Funke et al. (2007) further report that the hoarding of water by the Dutch led to the end of the traditional way of life for the KhoiKhoi pastoralists and the San hunters who depended on the gathering of wild animals at waterholes. British rule of the Cape Colony began in 1805 and continued the formalization of the riparian principle. The next 100 years saw the rise of British irrigation and the discovery of gold. Legislation was passed to grant water rights for irrigation and mining with priority over other uses while provision for rural water supplies was largely ignored.

The National Party came to power in 1948 and established apartheid, formalizing the creation of non- White areas where Blacks were forced to settle. To promote economic development, 
larger water projects were constructed for the benefit of the White population. The apartheid government's Water Act of 1956 emphasized provision of water for landowning (White) farmers. Under this act, groundwater was considered a private good, owned by whoever owned the land on which the borehole was established. Groundwater could be used by the borehole owner with basically no restrictions. The majority Black population was increasingly cut off from access to water and proper sanitation. It could be construed that water was used as a means of oppression and control as Black "homelands" had to negotiate their water rights with the apartheid government (Funke et al. 2007). Through the 1970s, the economic benefits of water control for the White population expanded into the energy and industrial sectors. By 1990, millions of Black South Africans had no access to a safe water supply or sanitation. Estimates vary considerably. According to the World Health Organization (WHO)/UNICEF joint monitoring program, $17 \%$ of the population, about 6.5 million people, had no access to safe drinking water in 1990 while $31 \%$ had no access to proper sanitation. The South African Department of Water Affairs, on the other hand, estimated that by 1994, 35\% of South Africans had no access to safe drinking water and 53\% had inadequate sanitation (Funke et al. 2007). In the new democratically elected government of 1994, provision of basic water supply and sanitation was given a top priority.

The basis of the revolutionary changes to water policy can be found in Section 24 of the Constitution's Bill of Rights (South African Constitution Act 108 1996) which guarantees all South Africans the right "to an environment that is not harmful to their health or well-being and to have the environment protected, for the benefit of present and future generations through reasonable legislative and other measures that prevent pollution and ecological degradation; promote conservation; and secure ecologically sustainable development and use of natural resources while promoting justifiable economic and social development."

The Water Services Act (RSA 1997) was enacted to improve the access to clean water and sanitation. Providing these services was part of redressing past racial and gender discrimination by improving health and freeing "poor black women and children from the unpaid drudgery of supply of domestic water" (Schreiner and van Koppen 2003). As Barbara Schreiner put it in 2001, South Africa must have a strategy "that ensures that poor men and women have access to the water resources that they need in order to build and maintain sustainable livelihoods, in order to escape from poverty" (DWAF 2003).

The 1997 White Paper on National Water Policy (DWAF 1997) presented water-law principles based on the Constitution which were then encoded in the NWA of 1998 (RSA 1998). One of the key principles was equitable access, which involves principles of efficiency, decentralization and sustainability (Funke et al. 2007). Addressing the principle of equitable access, the NWA established the concept of water as a common good rather than a private good. Most important was the establishment of a Reserve, the water required to meet basic human needs (set at $25 \mathrm{~L}$ /day per person) and to maintain environmental sustainability. Only this Reserve is guaranteed as a right. All other water uses, assuming they are deemed beneficial to the public 
interest, are subject to a system of allocation using licenses and general authorization. The allocation system should "promote use which is optimal for the achievement of equitable and sustainable economic and social development" (DWAF 1997). The previous allocation system based on riparian rights was abolished. The NWA, therefore, was not simply about water allocation. It was a means to alleviate poverty and promote gender equality (Schreiner and van Koppen 2003). Poverty and lack of access to an adequate water supply are closely correlated. Beyond meeting basic health needs, water is required for agriculture, raising livestock, fishing, and many small industries. When water is scarce, as in large areas of South Africa, water has traditionally been allocated to higher-income enterprises, thus hurting the poor even more. The NWA created a system of water allocation that guaranteed meeting basic human needs and recognized the economic needs of subsistence fishing and farming, small enterprises that depend on natural materials, opportunities for recreation and ecotourism (MacKay 2000). By divorcing water allocation and land ownership, not only were the needs of the poor recognized, but women were also empowered. Women have traditionally been the decision makers on farms more often than not, despite not being the official land owners. The NWA allowed water rights to be granted to female farmers without land titles (Schreiner and van Koppen 2003).

To help ensure efficiency, economic instruments have been adopted. The water guaranteed for basic human need is government-subsidized at no cost to the water user. Beyond the $25 \mathrm{~L} /$ day per person, a system of sliding tariffs has been adopted where water charges are proportional to water use in recognition that poorer people tend to use less water for their enterprises. Such a policy allows the value of water to poor communities to be considered along with the profit-making value of water for the wealthier sectors derived from large-scale irrigation and mining. Legalization of water use has also been formulated in recognition of the importance of smaller-scale use. For example, in areas without water stress, farmers are authorized, without the need for a license, to irrigate up to 25 ha at $6,000 \mathrm{~m} 3 / \mathrm{ha} /$ year. Allocations that require licenses must be issued "to redress the results of past racial and gender discrimination" (RSA 1998, part 8, section 45). Subsidized programs for development of low- cost technologies have been promoted.

The former Water Act of 1956 made no provision for public participation in the water management and allocation process. The 1998 NWA enabled the formation of catchment management agencies conforming to the 19 water management areas that correspond to South Africa's major watersheds. The catchment management agencies are required to seek input and agreement from local stakeholders and interest groups that ideally should represent both poorer small-scale and larger-scale water uses. Those affected by licensing decisions have the right to full disclosure of the licensing rational, to voice their opinions and concerns and to appeal the decision. Thus, water allocation was driven by interest-based negotiations rather than by land-based rights. Over time, water management should continue to decentralize, gradually moving from the dominant oversight by the Department of Water Affairs and the Environment to the point where the local catchment management agencies play the primary role. There exists, however, a huge challenge in redressing past inequalities through public 
participation. Water-use registration and the formation of Water Users Associations remain difficult for South Africa's majority poor Black population who do not share a history of past water registration, negotiations and organization.

\section{A utilitarian approach towards ecological sustainability}

So far, the emphasis has been on the component of the Reserve for meeting basic human needs. However, the other equally important component is that which is set aside for sustaining aquatic ecosystems. The NWA deviates from previous water policy in that it considers not just the state of the river water, but of the entire resource including the water, the surrounding landscape, the biota and their interactions. The 1998 NWA adopts a philosophy of integrated water-resource management, recognizing that a catchment's precipitation, surface water and groundwater are part of a common resource. Protection of the ecological integrity of an aquatic system comprises protection of the system's biological and habitat integrity representing a system's ability to maintain a diverse, balanced, integrated and adaptive community of organisms and physical and chemical characteristics with a functional organization comparable with that of a natural habitat within the same region (Harris et al. 1999). The environmental flow requirements of aquatic systems must be determined. Ecosystems are not required to be necessarily pristine, but some ecological integrity must be preserved. Two concepts inherent in the NWA's approach are those of an optimized and a threshold consumptive water use (Seward 2010). The assumption is that there is an optimal amount of water in a resource that can be used consumptively, so that the combined benefits from out-of-stream consumptive use and in- stream uses (including ecosystem integrity) are maximized. As the consumptive benefits increase, the non- consumptive benefits decrease. The assumed general pattern is that the total benefits will increase at first, but as consumption continues, the marginal benefit decreases as does the total benefit (Fig. 2). The threshold assumption is that ecosystems can withstand a certain amount of change or perturbation and still be sustainable. When that amount is exceeded, however, in this case by exceeding a maximum sustainable rate of water consumption, the ecosystem's integrity will be compromised.

The NWA's emphasis on ecological sustainability is based on a utilitarian ethic, one that emphasizes sustaining environmental health for human benefit. The Reserve's ultimate purpose is not simply to protect aquatic species for their own sake. Contrary to common misperceptions, establishing the ecological Reserve is not a matter of pitting the needs of human beings against the needs of other species. Rather, the idea of the ecological Reserve is again a means to a socio-economic end. Ecological sustainability is intended to provide "an equitably distributed package of desired goods and services (socioeconomic state) to society and not to protect ecosystems per se " (van Wyk et al. 2006). This approach recognizes that a healthy ecosystem is one that provides for both onsite use (non-extractive) and the more traditional offsite use (extractive). Onsite uses may include domestic water use and water for small-scale irrigation and raising of livestock, but the economic benefits of a healthy river system also include the ability to hunt and forage for food, gather building and craft materials, 
find natural pharmaceuticals and develop industrial products. Healthy river systems also have the ability to attenuate flood damage, maintain water quality through filtering and phytoremediation, and provide for some level of waste disposal, recreation and even spiritual needs. The NWA therefore calls for balancing onsite and offsite uses of water and necessitates ongoing negotiations. "The Ecological Reserve is a technical tool intended to be used in an interactive manner to establish connection between desired states of availability of river goods and services and the ecological state of the river" (van Wyk et al. 2006). So, like the Reserve component guaranteed for basic human need, the Ecological Reserve is also designed to redress past water inequities. The recognition and elevation of onsite uses of a river ecosystem benefit that part of the South African population whose lifestyles, means of sustenance and livelihood were previously not considered. Under the Water Act of 1956, water could be designated for economic development by the White population without thought given to the impact of such water use on river ecosystem health. Adoption of this utilitarian, anthropocentric philosophy of ecological protection incorporates the recognition of the diverse nature of river goods and services as well as different lifestyles, values and means of livelihood. The system adopted in the 1998 NWA values both onsite and offsite water uses despite the much higher market value associated with the large-scale offsite water applications. Onsite uses are now officially recognized and valued despite the difficulty of establishing their economic market value. It should be noted here that determination of the Reserve for a groundwater system only legally pertains to groundwater's role in preserving aquatic ecosystems. Its role in sustaining terrestrial ecosystems and land-based phreatophytes is not covered in the NWA (Xu et al. 2000).

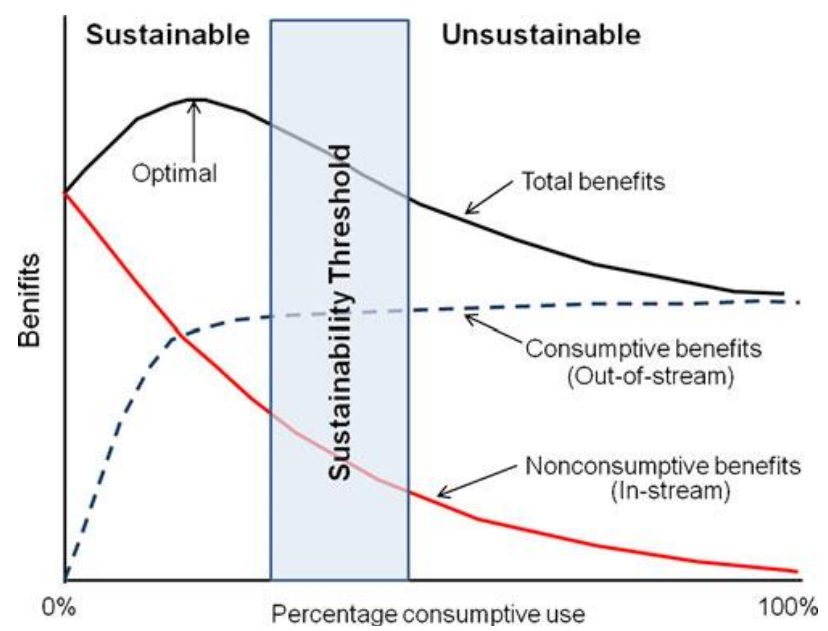

Fig. 2 Benefits of water use vs. percentage of consumptive use (Seward 2010, adapted from McCartney et al. 2000) 


\section{Resource directed measures}

South Africa seeks to simultaneously achieve the goals of efficiency (using water for the optimum social and economic advantage), equity (providing every citizen with access to an adequate and clean water supply) and sustainability (maintaining water quantity and quality and a healthy environment; Parsons and Wentzel 2007). The goals are summarized in the succinct phrase, "Some for all, forever" (MacKay 2000). "Some" recognizes the tradeoffs inherent in the process and the realization that no entity will have all the water it might desire. "For all" encompasses the desire to redress past inequalities and establish equity in water provision. "Forever" encapsulates the notion of sustainability. Methods to achieve this balance are outlined in Chapter 3 of the NWA, Protection of Water Resources (RSA 1998) and comprise three principal parts: resource classification, determination of the Reserve and establishment of resource quality objectives (RQOs). These three components are collectively known as resource directed measures (although the term never appears in the NWA). The policies are directed not just at a water source or at water quality, but at the entire resource including the water, the biota, the physical habitats and all the physical, chemical and biotic processes that provide the links between these components. Integration is a key concept of resource directed measures and includes integrating water quality and quantity, surface water and groundwater as well as rivers, lakes, wetlands and estuaries (DWAF 2003).

Resource classification begins with defining and delineating a water-resource unit based on common geographic, geologic, hydrologic and biotic characteristics. Its ecological functioning, geomorphology, water quantity, fluxes and quality must then be described (DWAF 2003). Classification itself involves determining a resource's present and desired status (Parsons and Wentzel 2007). The present status is determined based on the deviation from what is believed to be the natural, virgin condition of the resource. It is evaluated in terms of the degree of utilization and stress, water quality, habitat integrity and ecological functioning. Next, the ecological, social and economic importance of the resource is established. For this determination consideration is made for the diversity and rarity of the biota, the sensitivity of the ecosystem, the current uses of that system (both in-stream and out-of-stream) and the importance of the ecosystem for waste attenuation and flood control, as well as the ecological sensitivity of the resource and the potential impacts of water use. The desired management class defines the vision and goals for the resource. To achieve that vision from the present status, the Reserve is determined and the RQOs are designed.

The Reserve is determined for the benefit of present and future human consumption and ecosystem functioning and must be defined in the context of the resource classification, i.e., in terms of the management class that is to be achieved. Defining the Reserve is then the process of defining the water levels, flows, fluxes or volumes necessary to provide at least $25 \mathrm{~L}$ /day per person using the resource and to maintain the sustainability of ecosystems affected by the resource. 
Resource quality objectives are a set of clear goals that balance resource development and protection based on the resource's classification and the Reserve determination. Resource quality is a more encompassing concept than water quality. RQOs can refer to requirements regarding water use; the quantity, pattern or timing of river flows; water levels; physical, chemical or biological water quality; the character and condition of in-stream and riparian habitats; or the character, condition and distribution of aquatic biota (DWAF 2003). It is also suggested that the borehole (source-water) protection zoning could be included in the requirements of the RQOs. The RQOs are ideally defined with broad stakeholder participation, and they define the limits of acceptable development (i.e., acceptable risk) using parameters that can be numeric or descriptive, but need to be simple and measurable (Parsons and Wentzel 2007). For groundwater resources, RQOs may be set to avoid damaging ecosystems, drying up springs and other boreholes, saltwater intrusion, land subsidence or formation of sinkholes (Seward et al. 2006). Groundwater RQOs typically apply to groundwater quality, levels, gradients, pumping rates and land use including prohibition of certain activities within delineated protection zones (Parsons and Wentzel 2007).

\section{The role of groundwater/surface-water interactions in resource directed measures}

The implementation of the NWA, especially the determination of the Reserve and the setting of RQOs, requires an improved understanding of hydrologic processes in South Africa. One particularly important area of study in this context is groundwater/surface-water interactions. Development or contamination of one commonly affects the other, and therefore, a basic understanding of interactions is necessary for effective management of South Africa's increasingly stressed water resources. Interactions take place in almost any landscape, and surface water and groundwater are usually interconnected. Much research has been performed on interactions between groundwater and surface water. Nevertheless, the mechanisms occurring during these interactions are not yet fully understood. The difficulty to completely comprehend hydrologic problems on all scales has led to tendencies to separate hydrology from the disciplines with which it is most related: meteorology, climatology, ecology, geomorphology and geology. The same motivations have led to the separation of groundwater and surface-water hydrology (Klemes 1983). Although groundwater and surface water are part of one hydrologic cycle, hydrologists are divided into groundwater and surface-water camps, both using different terminology to describe the interactions, and both often quantifying the interaction component as a residual term in their water balance. In practice, the study of interactions in South Africa has suffered because most areas have had a historic focus on either groundwater or surface-water monitoring, which makes studies of exchanges very difficult.

South Africa is a relatively dry country with an average annual precipitation of $500 \mathrm{~mm}$. It is among the 20 most water-scarce countries in the world (Woodford et al. 2005). Even though groundwater accounts for only $15 \%$ of the volume of water used in South Africa, it is the sole source of water for $65 \%$ of the population (Woodford et al. 2005). Unlike surface water, $98 \%$ of which has been developed (McKune 2009), groundwater in South Africa has not been 
developed to its full potential; only about $6 \%$ of the estimated groundwater exploitation potential is being utilized. It is estimated that by 2025 , South Africa's water demand will exceed its supply (Roberts 2010). It is reasonable to assume that, in the future, groundwater will be extensively used to supplement current water supplies in South Africa (Woodford et al. 2005; $\mathrm{Xu}$ et al. 2000). Groundwater development under the NWA requires first the establishment of groundwater-resource units. For each unit, the amount of allocatable groundwater must be calculated, taking into account the resource's basic human-need and ecological Reserve. Groundwater ecosystems per se, which might comprise most microbial and stygofaunal communities, are not actually accounted for in the NWA. Instead, the ecological Reserve for groundwater is the groundwater that discharges to rivers, lakes and wetlands and is sometimes the only source of those resources and typically a crucial component of sustaining ecological integrity of surface-water systems. As quantification of those discharges can be complex, there are a variety of techniques available, some of which have been regularly applied in South Africa and some that have not. In addition, there is some debate regarding how to apply the quantifications of groundwater/surface-water interaction to the implementation of the NWA.

In 2007, the Department of Water Affairs and Forestry (now the Department of Water Affairs and the Environment) and the Water Resources Commission of South Africa published a report documenting how to apply resource directed measures to groundwater systems. In that report (Parsons and Wentzel 2007), a water-balance approach is taken (e.g., Wright and Xu (2000) in which the amount of groundwater that can be allocated for extraction and consumption (GWallocate) was defined as: GWallocate $=(\mathrm{Re}+\mathrm{GWin}-\mathrm{GWout})$ " BHN - GWb£ (1) where Re is groundwater recharge from precipitation, GWin is groundwater inflow, GWout is groundwater outflow, BHN is basic human needs and GWBf is ground- water contribution to baseflow. All of the terms in Eq. 1 are average annual values. In this case, baseflow is defined as low-amplitude high-frequency flow in a surface-water body that can come either from groundwater or interflow. In Eq. 1, BHN and $\mathrm{GW}_{\mathrm{bf}}$ constitute the Reserve assuming that the groundwater contribution to baseflow is the flow required to sustain surface-water ecosystems. If the resource unit is a groundwater basin where the only subsurface outflow is discharge to surface-water bodies, then the groundwater allocation is simply the groundwater recharge minus the Reserve. In a natural system in steady state, the recharge is equal to the groundwater discharge to surface-water bodies. Therefore, what $\mathrm{GW}_{\mathrm{Bf}}$ actually represents is the minimum amount of groundwater discharge that is required to sustain the ecological integrity of surface-water resources. In the case of rivers, this is an important component of the in-stream flow requirements.

Seward (2010) and Seward et al. (2006) regard the approach represented by Eq. 1 as conceptually flawed. First, they point out that the average annual recharge does not represent sustainability. There will be prolonged periods when a groundwater system does not receive the average value, at which time the calculated allocation would represent over-extraction. Second, they describe how ecologically important groundwater discharge can be lessened by any amount of pumping; there may be no safe amount to extract before these fluxes are 
unacceptably reduced. Pumped groundwater must come from one of three sources: (1) a change in storage and a resulting decline in the potentiometric surface, a source that by definition is not sustainable; (2) an increase in recharge such as capture of water from adjacent aquifers or surface-water bodies; or (3) a decrease in discharge including reduction in baseflow, spring flow, reduced yields from other borehole or reduced water extraction by phreatophytes. Seward et al. (2006) recognize that any groundwater extraction is likely to eventually affect groundwater discharge rates. There is, therefore, no single "safe" or "sustainable" groundwater yield, but only a range of permissible yields that depend not only on physical aquifer properties, but also on balancing social, economic and ecological concerns. Seward et al. (2006) therefore advocate adaptive management in recognition that our knowledge of groundwater systems will always be inadequate. Groundwater licensing and extraction should be a well-planned iterative process based on good modeling of the groundwater system (conceptual or mathematical), monitoring the effects of the abstractions and adjusting the licensing as necessary.

The approaches advocated by Parsons and Wentzel (2007) and that presented by Seward et al. (2006) are actually not necessarily in conflict. Seward et al. (2006) challenge DWAF's approach by arguing that the water- balancing process does not account for where the water is coming from. While Parsons and Wentzel (2007) may not be explicit, it is clear that the abstracted water is assumed to come from that part of the groundwater discharge that is not essential for ecologically integrity. Parsons and Wentzel (2007) state that the groundwater allocation is "the volume of groundwater that can be abstracted from a resource unit without impacting the ability of groundwater to sustain the Reserve." So, in fact, the groundwater allocation is accounted for by some capture of discharge. Also, the balancing of social, economic and ecological concerns is inherent to the definition of the Reserve. The case studies that are discussed by Seward et al. (2006), however, do indicate that the major problem with the water-balance approach is that the process applies to the entire resource unit without consideration of local effects. An extraction amount that might be theoretically sustainable on the basin scale may not be sustainable at the borehole scale. Pumping from a borehole may unacceptably reduce discharge to sensitive springs, wetlands or riparian zones even if the groundwater unit is not appreciably harmed at the basin scale. Predicting local effects requires more detailed knowledge of the spatial heterogeneity of aquifer characteristics and calls for a more detailed modeling approach towards calculating the ground- water allocation. Seward et al. (2006) maintain that the positioning of boreholes with respect to other boreholes, discharge areas and recharge areas is the critical factor, not the calculation of terms in Eq. 1. To handle spatial heterogeneities of aquifer characteristics and to predict the impact of groundwater pumping on ecosystems, distributed groundwater models represent the best strategy (Xu et al. 2000). Parsons and Wentzel (2007) do recognize this issue, however, and advocate calculating appropriate setback distances and protection zones for boreholes as part of establishing RQOs to prevent damage to surface-water systems. 
No matter what general approach is applied, it is clear that estimating the water exchange between groundwater and surface-water systems is a crucial component of estimating the Reserve and calculating the groundwater allocation and therefore is crucial for the implementation of the NWA. To ensure that sensitive areas are not harmed by groundwater abstraction, it becomes important to not only estimate average annual fluxes, but also to characterize the spatial and temporal heterogeneities associated with groundwater/surface-water exchanges.

\section{Ecological implications of groundwater/surface-water interaction}

Understanding of the ecological needs of aquatic systems has evolved greatly in the past half century. For example, in the United States in the 1970 os and 1980s, the Tennant method was a widely-accepted approach for determining the amount of water a river needed (Postel and Richter 2003). Based on his research, Tennant suggested that $60100 \%$ of a river's average flow was needed to maintain "optimum" ecological conditions and 30-50\% to provide "excellent habitat." River protection in the US during this time was based partly on the belief that the low flows in a river were the principal constraint on ecosystem health. There was an emphasis on maintaining enough water to allow specific fish species to swim and migrate (Postel and Richter 2003). We now understand that aquatic ecosystems need a full spectrum of flows including both high and low extremes and that focusing on just a few fish species is too narrow an approach towards ecological protection. Instead, a growing array of scientists and managers recognize the importance of a "natural flow paradigm" in which water management should "protect and restore a river's natural flow variability" (Poff et al. 1997). In the 1990s, South Africa and Australia benefited by being relatively new to ecosystem management and therefore had the opportunity to prescribe ecological flows with newer ideas and more holistically, rather than having to change approaches (Postel and Richter 2003). South Africa has led the world in developing building block methodology, a holistic approach that accounts for and values natural flow variations and considers water quality, sediment transport, groundwater level, the physical habitat and a wide variety of species. Building block methodology involves collaboration among a team of interdisciplinary scientists including hydrologists and biologists. Economic development and ecological protection were balanced through the classification scheme of ecological health in recognition that not every river system would or should be protected to the same degree. The successful implementation of all these approaches hinges on different interested parties coming together to decide on the optimum level of ecosystem protection that provides economic opportunities in a socially just and sustainable way.

Groundwater's principal role in protection of a river's flow regime is its contribution to baseflow or low flow conditions, the dominant flow condition in most rivers. Groundwater/surface-water interactions, therefore, have a special ecological significance in terms of controlling habitat for many species most of the year. While not traditionally an area of intensive research, more and more research on groundwater-dependent ecosystems has recently been undertaken in South Africa. 


\section{Large-scale dependency}

Alterations in the pattern or magnitude of groundwater/ surface-water interactions often have very serious implications for water resources. In natural conditions over the long term, recharge is always balanced by discharge. In the past, there has been focus on safe yield-making sure that withdrawal of groundwater resources does not exceed natural recharge-but this approach is inadequate. The traditional "safe yield" (groundwater withdrawal at a rate equal to the rate of recharge) is not sustainable assuming that the definition of sustainability includes preserving ecosystems. The sustainable yield of an aquifer is considerably less than the natural recharge if adequate amounts are to be available to sustain quantity and quality of surface-water bodies and ecosystems (Sophocleous 2000). Water use equal to the amount of recharge will eventually result in the drying up of surface-water bodies and springs as no natural recharge is available for discharge. It can take years or even up to millennia for the effects of unsustainable withdrawal to be visible, but once they appear it also takes a long time to reverse the damage, if at all possible. Even less ambitious ground- water development can lead to long-term reductions in streamflow which can affect vegetation in riparian zones that, in turn, is a critical part of the riparian wildlife habitat and also often enhances the quality of surface water (Alley et al. 1999). Groundwater pumping can reverse hydraulic gradients so that previously gaining streams become losing streams. Such reversals affect aquatic life in the stream because of changes in surface-water temperatures, oxygen levels, nutrient concentrations and suspended sediment load, which in turn affects the amount of sunlight penetrating the water. In lakes, groundwater can be the principal source of dissolved nutrients even when it is a relatively small component of the water balance. Perhaps most sensitive to changes in groundwater discharge rates are wetlands where the amplitude and frequency of water-level fluctuations can affect the type of vegetation, the nutrient cycling and therefore the types and numbers of invertebrates, birds and fish that can be found. Reducing groundwater discharge to coastal environments can also lower the flow of nutrients damaging coastal plant and animal communities (Alley et al. 1999).

To avoid jeopardizing ecosystem functioning, the study of the water balance of water resources before alterations to the hydrologic regime are implemented is essential. The combination of hydrologic and ecological understanding is important to determine which restrictions should be placed on the use of water resources by urbanization and agricultural development. In arid and semi-arid climates such as those in much of South Africa, the ecological role of wetlands is even greater, and they are more vulnerable to high water demands. Only a sound understanding of the interdependence of water resources and ecosystems combined with an assessment of vulnerability and ecological importance can support decision-making.

Recommendations must consider that the healthy functioning of water resources often depends on chaotic processes with dramatic extremes. It is therefore not enough to ensure an average input to the ecosystems depending on interactions with groundwater. Focus should also be on the safeguarding of the cyclic nature of inflows and outflows. It must be recognized 
that not all ecosystems will react proportionally to changes in water availability; for some, the reaction will be abrupt when a certain critical value is exceeded. For many rivers throughout their dry season, streamflow is entirely base- flow, much of which is derived from groundwater. During such times, streamflow declines directly with loss of groundwater discharge into streams. Loss of flow can lead to sedimentation which changes the channel morphology affecting the distribution and abundance of stream biota. A lower water table under antecedent conditions can also reduce overbank flooding during high-flow events, which can damage riparian ecosystems.

The origin and the mixing of groundwater and surface water changes the water's chemical composition, acidity, temperature and dissolved oxygen, all of them major controlling factors in aquatic environments. Therefore the interactions also affect the vegetation and fauna in and around those ecosystems. Near-shore and phreatic wetland vegetation is sensitive to groundwater level recessions and reduced groundwater discharge. In freezing conditions, relatively warm groundwater inflow prevents smaller surface-water bodies from freezing, thereby sustaining vegetation and fauna populations and providing habitat. Groundwater also provides temperature moderation in surface water in the summer. The role of groundwater in sustaining vegetation also indirectly prevents erosion and large-scale (spontaneous) spreading of destructive fire. Additionally, eutrophication of lakes and wetlands has been observed after reduction of groundwater inflows.

\section{Small-scale dependency}

The diversity in hydrogeochemical conditions induced by water exchanges affects the diversity and composition of ecosystems (Shedlock et al. 1993). On the micro-scale, the focus of many studies is on the water-quality issues in and near the interface, i.e., the hyporheic zone. The exchange of groundwater and surface water in this zone has repercussions for water quality and the nature and abundance of biological communities (Hunt et al. 2006; Hancock et al. 2005). Fauna living in and near the interface are part of a food chain that sustains a diverse ecological community (Winter et al. 1998). Intensive biogeochemical activity occurs in the hyporheic zone, partly because of relatively long contact with reactive geologic materials (Sophocleous 2002). The hyporheic zone has a high capacity for contaminant attenuation because of high microbial activity and typically low hydraulic conductivity relative to the underlying aquifer. Even when there is no substantial net flux between groundwater and surface water, water may still move through the hyporheic zone and get enriched in dissolved constituents. Faunal composition, distribution and abundance reveal extraordinary patchiness and variability in the interaction zones due to heterogeneous sediment porosity and permeability and heterogeneous water characteristics such as temperature, and concentrations of dissolved oxygen, nutrients and organic matter.

In past studies, observations of hyporheic ecofunction- ing have highlighted the important role of the interface in the food web. Recharge of groundwater from surface water brings oxygen-rich water to a zone with limited oxygen, creating a habitat for many organisms ranging 
from microbiotic organisms to macro-invertebrates, some of which can colonize the groundwater system. In wetland streams in northern Wisconsin, USA, groundwater discharge to streams resulted in greater benthic invertebrate abundance, taxonomic richness and periphyton respiration (Hunt et al. 2006). Sediments and organic matter that are deposited during surface-water flows through the lakebed or riverbed are utilized by microbial organisms for decomposition. This process results in the release of nutrients that are beneficial to macro-invertebrates and other organisms such as stone flies, which then become food for fish and other aquatic organisms. In general, the diverse fauna and flora are feeding grounds for other species which leads to higher productivity, attracting larger species as well (Gardner 1999).

Groundwater plays a particularly interesting role in wetland ecology in the Okavango Delta (actually an alluvial fan) of northern Botswana, the most pristine of Africa's large wetlands (McCarthy 2006). Of the $10 \mathrm{~km}^{3}$ of water discharging onto the fan each year, only about $2 \%$ leaves as surface flow and groundwater flow; the rest is lost to evapotranspiration. Between 80 and $90 \%$ of the seasonal flood waters recharge the groundwater system raising the water table. During the rest of the year, the water table is steadily lowered through transpiration by aquatic plants in the flood plain and terrestrial plants on the islands. The island transpiration induces net ground- water flow towards the islands and silica and calcite precipitation beneath the island fringes with sodium bicarbonate precipitation in the island centers. This process builds the wetland islands vertically and then horizontally but leaves the island centers bare of vegetation. The seasonal cycling of this water helps to maintain low-salinity surface water and a diversity of physical wetland habitats (McCarthy 2006).

The interaction zone provides permanent or seasonal habitat for several species, and temporal refugia with shelter from high discharge areas, extreme temperatures, desiccation and predators. Spawning of fish and incubation of eggs frequently occurs where groundwater wells up in lakes and wetlands because of the adequate dissolved oxygen and warmer winter temperatures (preventing freezing). The hyporheic zone also has chemical buffering characteristics, cleaning capacity for pollutants and detritus trapped in sediment and denitrification capacity. The temporary capacity for subsurface-water storage also has an important flood-mitigation capacity. 


\section{Investigating groundwater/surface-water interaction: South African examples}

Since the implementation of the NWA, many studies investigating groundwater/surface-water interactions in South Africa were designed to help define the Reserve and guide the Department of Water Affairs in groundwater allocation. The quantification and even the conceptualization of these interactions is a major challenge, plagued by scale problems and the difficulty in estimating the properties of temporally and spatially heterogeneous hydrogeologic parameters (Sophocleous 2002; de Vries 2000). Conceptualization and quantification are especially difficult in the case of fractured-rock aquifers that cover most of South Africa (Seward et al. 2006). With fractured- rock aquifers, there can be great spatial variability of groundwater contributions to surface-water systems which may occur mainly where weathering and deformation have formed secondary porosity. Discharge may be concentrated in discrete locations rather than evenly distributed along a river, lake or wetland. Understanding the spatial distribution of discharge is needed to properly develop a groundwater system and calculate the ground- water allocation. These complexities warrant pursuing multiple techniques when quantifying interactions. Some of these methods are discussed in the following paragraphs and summarized in Table 1.

\section{Conceptual modeling and geochemistry: Groenvlei and Van Kervelsvlei wetlands case study}

As water demands grow in the Western and Southern Cape regions of South Africa, a major aquifer that may be increasingly utilized is the Table Mountain Group (TMG) aquifer in the Cape Fold Belt (Fig. 3), a folded thick sequence of fractured arenite and quartzite sandstones. It therefore becomes important to understand the nature of the TMG discharge to wetlands. Two wetlands that have been studied in some detail and present a particularly interesting case study are the Groenvlei and Van Kervelsvlei wetlands in the Southern Cape (Fig. 3).

Roets et al. (2008a) developed a conceptual model of TMG groundwater discharge to wetlands in the Southern Cape. They highlighted the importance of distinguishing groundwater discharge from interflow discharge to wetlands, suggesting that interflow was an important component in the TMG mountain catchments. If much of the stream baseflow is from interflow or flow from perched aquifers, emanating from perched springs, then baseflow will not be affected by regional groundwater development of the TMG. Roets et al. (2008a) hypothesized that TMG discharge in the headwater and mountain regions was minimal because the water table usually lies below stream level. Where it did occur, it was probably associated with deeply incised fractures, liniments, faults and geologic contacts. Roets et al. (2008a, b) believed that TMG discharge was more important in the foothills and became less important downstream where the underlying shale aquitards dominate. They contended that major faults on low-lying land, however, could result in deep pressurized TMG discharge that could contribute flow to overlying primary shallow aquifers (Roets et al. 2008b). Roets et al. (2008b) also used groundwater and lake geochemistry and electrical conductivity to conclude that water from the TMG discharged to both Groenvlei and Van Kervelsvlei and that the two lakes were hydraulically connected. 
Parsons (2009a) took issue with the conceptual model presented by Roets et al. (2008a, b) and used area elevations and groundwater elevations to conceptualize that the Van Kervelsvlei represented a perched system at an elevation well above the regional water table and was sustained almost solely by rain. Groenvlei wetland, on the other hand, was connected to the unconfined primary Quaternary-sand aquifer whose recharge came not from the TMG, but directly from precipitation. 


\begin{tabular}{|c|c|c|c|c|}
\hline Method & Scale of application & $\begin{array}{l}\text { Appropriate for } \\
\text { estimates in discrete } \\
\text { locations and/or } \\
\text { fractured bedrock } \\
\text { settings? }\end{array}$ & $\begin{array}{l}\text { Allows } \\
\text { quantification } \\
\text { of exchange? }\end{array}$ & $\begin{array}{l}\text { Example application in } \\
\text { South Africa }\end{array}$ \\
\hline $\begin{array}{l}\text { Seepage meters and } \\
\text { minipiezometers }\end{array}$ & In-stream point measurements & Yes & Yes & \\
\hline Heat-flow modeling & $\begin{array}{l}\text { In-stream point measurement } \\
\text { and short river reaches }\end{array}$ & Yes & Yes & \\
\hline $\begin{array}{l}\text { Upstream/downstream } \\
\text { flow measurements }\end{array}$ & $\begin{array}{l}\text { Individual river reaches with no } \\
\text { other unknown inputs/outputs }\end{array}$ & Yes & Yes & \\
\hline $\begin{array}{l}\text { Hydrometry/Darcy's } \\
\text { law/water balance }\end{array}$ & Entire basin or single lake or wetland & No & Yes & Parsons $(2009 \mathrm{~b})$ \\
\hline $\begin{array}{l}\text { Geochemistry and } \\
\text { temperature }\end{array}$ & Sub basin and individual river reaches & Yes & Yes & $\begin{array}{l}\text { Roets et al. }(2008 \mathrm{~b}) ; \\
\text { Winde et al. }(2004)\end{array}$ \\
\hline $\begin{array}{l}\text { Stable isotopes }{ }^{2} \mathrm{H} \\
\text { and }{ }^{18} \mathrm{O}\end{array}$ & Sub basin and individual river reaches & Yes & Yes & \\
\hline Baseflow separation & $\begin{array}{l}\text { Entire basin, quaternary catchments } \\
\text { or section of basin upstream from } \\
\text { point of stream monitoring }\end{array}$ & No & Yes & $\begin{array}{l}\text { Herold (1980); Hughes et al. } \\
\text { (2003); Le Maitre and } \\
\text { Colvin (2008); Nathan and } \\
\text { McMahon (1990); Smakhtin } \\
\text { (2001b); Vetger (1995); } \\
\text { Xu et al. (2002) }\end{array}$ \\
\hline Conceptual modeling & Entire basin or section of a basin & Possibly & No & $\begin{array}{l}\text { Parsons (2009a); Roets et al. } \\
(2008 \mathrm{a}, \mathrm{b})\end{array}$ \\
\hline Numerical modeling & Various, up to entire basin & Yes & Yes & $\begin{array}{l}\text { Kelbe and Germishuyse (2000); } \\
\text { Rawlins and Kelbe (1998) }\end{array}$ \\
\hline Vegetation mapping & Various, up to entire basin & Yes & No & $\begin{array}{l}\text { Le Maitre et al. (1999); } \\
\text { Rawlins and Kelbe (1998) }\end{array}$ \\
\hline
\end{tabular}

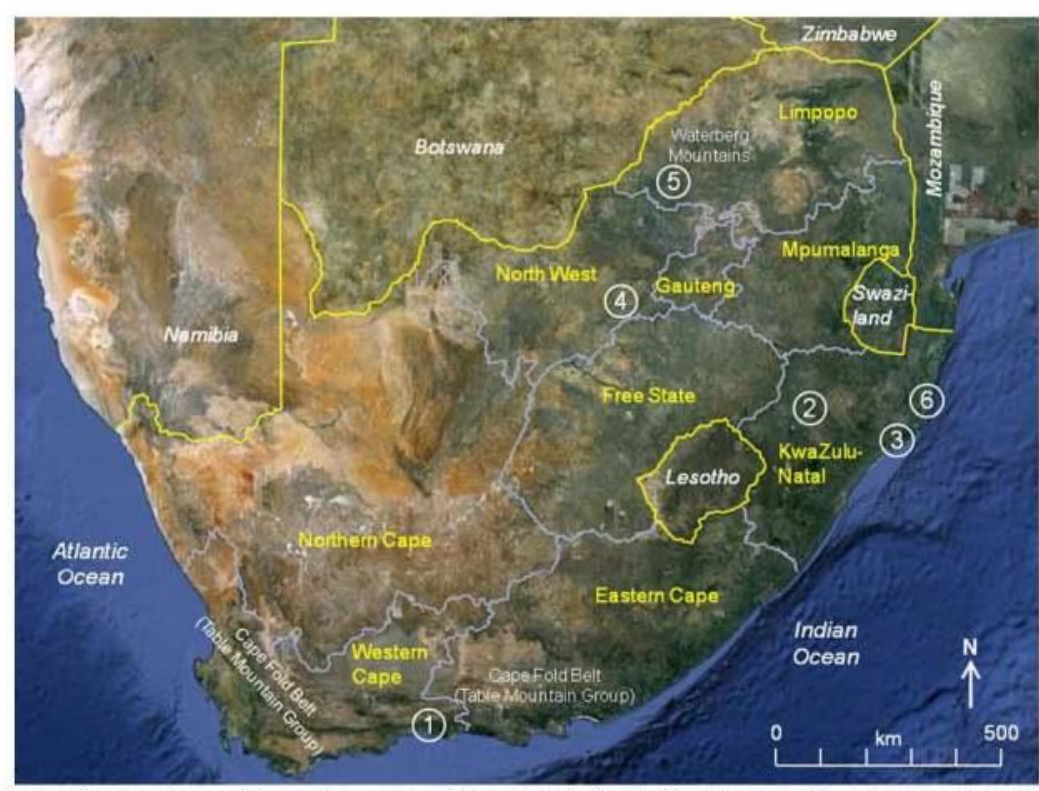

Fig. 3 South African Provinces and case-study locations: ( $($ ) Groenvlei and Van Kervelsvei wetlands; (2) Thukela River basin; (3) Richard's Bay and Lake Mzingari; (4) Koekemoerspruit River, (5) Thabazimbi District; (6) Lake St. Lucia. (Base image courtesy of Google Earth) 


\section{Application of the water-balance approach and Darcy's law to the Groenvlei and Van Kervelsvlei wetlands case study}

Parsons (2009b) went beyond development of a conceptual model to quantify the groundwater discharge into Groenvlei. He first applied a water-balance approach. Rises of water level in the lake could be accounted for solely by direct precipitation, and there was no surface- water outflow from the lake. The water balance simplified to just terms for groundwater flow into and out of the lake, direct precipitation, evapotranspiration and changes in storage. Direct precipitation and evaporative losses were measured in the field as was the change in lake storage. The net contribution from groundwater was then calculated as $2.04 \mathrm{~mm} / \mathrm{day}$. As an alternative method, Parsons (2009b) applied Darcy's law using measured hydraulic gradients, aquifer transmissivity and the width of the inflow and outflow sides of the lake. The Darcian approach yielded an estimate of 2.74 and $0.71 \mathrm{~mm} /$ day groundwater inflow and outflow, respectively, with a net groundwater contribution of $2.03 \mathrm{~mm} /$ day, in close agreement with the mass-balance approach.

The Groenvlei and Van Kervelsvlei wetlands case study demonstrated many important points. First, it is crucial to develop a proper conceptual model that agrees with the interpretations of local geology, hydraulic gradients and topography. Second, geo/hydrochemistry offers a way of relating and differentiating groundwater from different sources. Characterization of the spatial variability of chemical parameters in surface water can help identify areas and amounts of groundwater recharge. Although providing much valuable information, such methods are indirect, and chemical correlation does not prove causation. Finally, the case study indicates that basic hydrologic (precipitation, evaporation) and hydrogeologic investigations (hydraulic gradients, aquifer transmissivity) can yield sound estimates of groundwater contributions.

The volumetric flows calculated by Parsons (2009b) do not directly allow the estimation of the groundwater allocation. Investigations are still needed to estimate how much of that groundwater discharge is necessary to maintain the ecological integrity of the wetlands. Also, while the methods yielded annual average flow rates, estimates of flow and flow requirements are also needed for extreme dry conditions.

\section{Consideration of local impacts}

The water balance approach is one that can be applied to any surface-water body to help resolve the amount of groundwater contribution. Typically, this approach is applied to large areas and therefore overlooks the local impacts that may be associated with individual boreholes. Water may be pumped from a single borehole in small enough amounts to be deemed sustainable for the entire resource unit and yet may have a negative impact on nearby sensitive aquatic ecosystems (Wright and Xu 2000). Such local effects can be regulated with proper resource quality objectives designed to delineate proper set-back distances of boreholes from sensitive areas or delineating protection areas around those sensitive areas. The official 
Groundwater resource directed measures manual (Parsons and Wentzel 2007) describes several such methods. For example, assume that $Q_{E R}$ is the required environmental flow for a river reach of width $W$. If the recharge rate is estimated as $\mathrm{R}$, then the protection area for that river reach is defined as $\mathrm{LW}$ where $\mathrm{LWR}=\mathrm{Q}_{\mathrm{er}}$. A similar approach is presented for calculating a protection area for a circular wetland. The fallacy in such methods, however, is the assumption that groundwater extraction from outside the protection area will have no effect within the protection area. In actuality, pumping outside the area will lessen the hydraulic gradients and saturated thickness within the protection area, thus reducing flow to the sensitive ecosystem. The methods presented also assume aquifer homogeneity. Of course, a preferred, more sophisticated approach would be to assess the impacts of pumping using numerical modeling that allows for aquifer heterogeneity and temporal variability (Wright and $\mathrm{Xu} 2000$ ).

\section{Baseflow separation techniques}

For streams and rivers, an additional method for estimating the groundwater contribution is baseflow separation. At any time, flow in a stream is assumed to come from some combination of overland flow (or surface runoff), a groundwater contribution, interflow and direct precipitation. Many empirical techniques are available for separating a hydrograph of total streamflow into its two principal components: high-frequency low-amplitude baseflow and low-frequency, high-amplitude flood flows (Hughes et al. 2003). Such separations are based on physical reasoning, but the quantitative elements of the separation techniques are essentially arbitrary (Nathan and McMahon 1990). In fact, separation ofbaseflow from surface runoff has been described as "one of the most desperate analysis techniques in use in hydrology" and "that fascinating arena of fancy and speculation" (Nathan and McMahon 1990). Techniques either assume that baseflow responds to storm events concurrently with surface runoff or they assume that baseflow recession continues after the time when surface runoff begins. Depending on the approach, different assumptions are made regarding the timing of peak baseflow and the timing of when surface runoff is assumed to cease.

Hydrograph separation techniques can be applied to event-based hydrographs (using usually daily or hourly data) or long-term periods of a year or several years. When applied to long-term hydrographs, they are referred to as continuous separation techniques.

Hydrograph separation allows estimation of baseflow or low flow, the flow in a stream that is sustained during prolonged dry weather (Smakhtin 2001a). This low flow might be derived from delayed sources such as discharge from lakes or wetlands or from melting glaciers, but in most systems, baseflow is derived principally from groundwater discharge and interflow or spring flow. Hydrograph separation does not differentiate between sources; other methods must be used for that differentiation. Spring flow can be important especially in steep terrain and in arid and semi-arid areas where the water table is below stream level.

The hydrograph separation technique of Herold (1980) was adopted by South Africa in the Water Resources 1990 project to estimate the groundwater component for about 2,000 quaternary catchments in South Africa, Lesotho and Swaziland (Xu et al. 2002). The Herold 
technique makes monthly estimations of the groundwater contribution to streamflow by assuming that during each month, the ground- water contribution will not drop below a certain amount that is dependent on the previous month's groundwater contribution and surface runoff and factors for decay and growth of the groundwater component. The growth and decay factors are estimated through visual calibration so that a realistic separation is achieved (Parsons and Wentzel 2007).

$\mathrm{Xu}$ et al. (2002) improved on the Herold technique by taking into account the hydrogeomorphologic setting of the reach of river being considered. They suggested different ranges of values for the growth and decay factors based on the river-segment location (upper, middle or lower part of the catchment), the likely importance of bank storage, whether the river is braided or meandering and whether the water table is above or below river stage.

One user-friendly automated hydrograph-separation technique is the recursive digital filter. This technique can be used either on daily or monthly streamflow data according to the following algorithm (Hughes et al. 2003):

$$
\begin{aligned}
& \mathrm{qi}=a q \mathrm{i}-1+\mathbf{b}(1+\mathbf{a})\left(\mathrm{Qi}-\mathrm{Qi} \_\mathrm{x}\right) \\
& Q B \mathrm{i}=Q \mathrm{i}-\mathrm{qi}
\end{aligned}
$$

where:

$Q_{i} \quad$ Total flow time series

$q_{i} \quad$ High flow time series component

$Q B_{i} \quad$ Baseflow time series component

i Timestep index

$a, 3$ Separation parameters, $(0<a<1,0<3<0.5)$

The separation parameters are used for calibration based on visual inspection. In its original formulation, 3 was a constant set as 0.5 (Smakhtin 2001b; Nathan and McMahon 1990). Baseflow is constrained to be never $<0$ or $>$ Q. High $a$ values produce low baseflow volumes and vice versa.

The recursive filter algorithm has been used successfully in South Africa with daily stream flow data, 3 equal to 0.5 and $a$ values between 0.985 and 0.995 (Smakhtin 2001b). Smakhtin suggested that to apply the recursive filter algorithm to monthly data, the a values should be calibrated so that the results match those using the daily stream flow data. He found that using monthly data, $a$ values of 0.925 were more appropriate for catchments with between 600 and $1,100 \mathrm{~mm} /$ year precipitation. Values might be $2 \%$ higher in regions with $<600 \mathrm{~mm}$ precipitation and $2 \%$ lower in regions with $>1,100 \mathrm{~mm}$. Hughes et al. (2003) additionally found that better results were obtained when 3 was allowed to vary, typically between 0.43 and 0.47 , resulting in simulations that were more realistic with respect to the timing of peak base flow. None of the methods discussed is able to differentiate between ground- water discharge and interflow. Xu et al. (2002), however, do offer criteria for deciding when interflow might be an important component of the hydrograph. 


\section{Estimates on a national scale}

Through the use of baseflow-separation techniques, annual groundwater-fed base flow estimates were calculated by DWAF (2005) for all quaternary catchments in South Africa, Lesotho and Swaziland and expressed in terms of a base flow index, the fraction of a river's mean annual runoff emanating from groundwater discharge and interflow. Le Maitre and Colvin (2008) explored the relationships of these estimates to other catchment characteristics to identify, on a national scale, the characteristics that best indicate the groundwater contribution to rivers. One important characteristic was the percentage of zero-baseflow months, a possible indicator of the fragility of the river system with respect to groundwater development. Le Maitre and Colvin (2008) found that catchments with baseflow indices $>0.35$ were associated with no zero flows. Catchments with baseflow indices $<0.35$ had variable zero flows. For example, catchments with a baseflow index of 0.16 had anywhere between 0 and $90 \%$ zero flows. The mean baseflow index for aquifers comprising unconsolidated deposits was only 0.10 due to the predominance of sand aquifers in the Kalahari region. For other principal aquifer types (Fig. 1), the mean baseflow indices ranged from 0.24 for Karoo dykes and sills to 0.37 for carbonates. The amount of baseflow was directly related to the episodic nature of the baseflow. Greater variability in the seasonal baseflow indicated a lower baseflow index $(r=-0.91)$. One exception to this relationship was in the Waterberg Mountains (Fig. 3) where groundwater discharge was sustained throughout the year despite low mean annual rainfall. This was explained by the presence of discharge from deeper aquifer systems along dykes and faults. In general, catchments dominated by carbonates, the Table Mountain Group and basement complex aquifer types were more likely to have more consistent groundwater discharge throughout the year (Le Maitre and Colvin 2008). Le Maitre and Colvin (2008) concluded that there was no one statistic to provide a meaningful index of the groundwater contribution to a river, but that both the magnitude and seasonal variability of baseflows should be part of any assessment. The proportion of zero flows was also a good indicator of the variability of flow.

Vetger (1995) created a set of national maps quantifying the spatial distribution of estimated average hydro- logic fluxes including groundwater recharge and groundwater contribution to river flow. This latter map is used by Groundwater Resource Directed Measures software to provide an initial indication of the groundwater contribution (Parsons and Wentzel 2007). The map is based on baseflow estimates using the Herold baseflow separation method (Herold 1980) applied to catchments all over South Africa. It is interesting to note that, according to this map, rivers throughout the majority of South Africa, in the arid and semi-arid areas, have negligible groundwater contribution to river baseflow. Parsons and Wentzel (2007) warn that such maps should be used cautiously as not all baseflow is derived from groundwater and ideally, groundwater contribution estimation should be based on more detailed and site-specific information. 


\section{The Thukela basin: an example on a regional scale for application of groundwater reserve determination}

In 2008, DWAF began the determination of the groundwater reserve for the entire catchment of the Thukela River (Fig. 3), the third largest river in South Africa with 8.5\% of the country's entire streamflow (Dennis 2008). The $30,000 \mathrm{~km}^{2}$ catchment (considered a primary catchment in South Africa) comprises 88 fourth-order catchments ranging in size from 105 to 747 $\mathrm{km}^{2}$. The Thukela catchment encompasses large conservation areas and many waterfalls and gorges of ecological significance as well as the Royal Natal National Park and World Heritage Site. The preliminary groundwater reserve determination in this inception report was performed by using the water- balance approach on each of the 88 sub-catchments. For each sub-catchment, national data were used to estimate the average annual recharge rate (the method used is unclear, possibly the chloride method). The groundwater/ surface-water interaction was estimated for each sub- catchment using estimates of the annual groundwater component of baseflow. Presumably, these estimates were made using the Herold method of hydrograph separation (not explicitly stated). Basic human needs were also estimated based on $25 \mathrm{~L} /$ day per person, a very minimal amount in this catchment. The groundwater reserve was assumed to be the sum of the basic human need and the baseflow. The groundwater reserve estimates for the 88 sub-catchments ranged from 27 to $80 \%$ of the recharge rate and averaged $43 \%$ for the entire Thukela catchment. The amount of groundwater that could be allocated was the difference between the average recharge rate and the groundwater reserve.

The Thukela catchment example highlights some of the philosophical debate regarding how estimates of the rate groundwater discharge to surface water should be applied to the determination of the groundwater reserve. In a review of the inception report, reviewers were critical of the application of the water-balance approach and pointed out that the inception report ignores the concept of capture -that sustainable use is based on the increase of recharge and decrease of discharge associated with groundwater abstraction ( $\mathrm{Xu}$ et al. 2008). More importantly, the inception report did not consider the complex effects associated with the location of production boreholes and their spacing or distance from recharge and discharge zones, nor did the report consider the temporal and seasonal variability of the groundwater discharge to surface water. The report used only average annual rates of recharge applied to quaternary catchments. Even if one assumes no uncertainty associated with the groundwater recharge and discharge estimates, such an approach does not at all ensure the sustainable viability of important ecological areas. Xu et al. (2008) assert that estimating groundwater recharge and discharge rates on a scale as coarse as or coarser than the quaternary catchment is therefore insufficient, but to do so everywhere on a finer scale is impractical. Instead, they recommended choosing discrete areas where protecting groundwater discharge to surface water is deemed to be especially important, a strategy that is supported by the National Water Resource Strategy (DWAF 2004). These areas should be selected based on public participation and stakeholder interests. Public participation should therefore be the starting point of groundwater resource directed measures, rather than an afterthought. This alternative approach recognizes that any groundwater development leads to diminished flows to surface 
water. Water-resource protection should entail deciding where diminished flows are economically, socially and ecologically acceptable and then implementing a groundwater-development plan in an adaptive, iterative way allowing proper monitoring of all the potential impacts on flows, water quality and even land subsidence. As Xu et al. (2008) insist, "There is no single, fixed 'safe' or 'sustainable' yield for a groundwater basin, but rather a range of 'permissible' yields dependent on how the groundwater is accessed-i.e. well-field proper- ties-and social, economic, and ecological concerns."

\section{Use of numerical modeling}

Model predictions are only as good as the information used in the construction of the model. Still, numerical groundwater-flow models are tools that can incorporate known aquifer geometry, parameter values and boundaries along with climatological, topographic and hydrologic data into a well-developed conceptual model to make the best estimations possible regarding all aspects of ground- water flow. Models have the advantage over other methods in that they can readily incorporate spatially heterogeneous and temporally variable information and help predict the effects of local impacts on ecologically sensitive areas. Once confidence is earned in a model's ability to simulate actual conditions, the model can be used to explore the effects of different groundwater/land- use scenarios or the effects of climate change.

One example of applying groundwater-flow modeling in the context of implementing South African water policy was a study of coastal lakes in the Richards Bay area (Fig. 3) of the coastal plain along South Africa's highly- populated and industrialized southeast coast (Kelbe and Germishuyse 2000). This area relies on these lakes for freshwater supply. Groundwater flow modeling was used to investigate the groundwater/surface-water interactions for Lake Mzingazi, a principal water-supply lake. The system was modeled using MODFLOW (McDonald and Harbaugh 1988), first with a steady-state simulation calibrated to a small set of dispersed water levels from nearby boreholes. Then a transient calibration was performed using time-series water levels in three boreholes in the lake's immediate vicinity. To better estimate groundwater-lake interactions, another calibration was performed adjusting the lake-bed hydraulic conductivity (in the form of MODFLOW's conductance). Lake-bed conductance was varied over three orders of magnitude, but an adequate simulation of lake levels was not achieved until a two-layer model was developed that incorporated a discontinuous layer of Miocene conglomerates with higher hydraulic conductivity that acted as a drain for water flowing from the lake to the ocean. Once calibrated, the model was used to characterize the lake's water balance including an estimate of the contribution of groundwater between 1980 and 1998. The results indicated that even given a low lake-bed hydraulic conductivity, the groundwater contribution to Lake Mzingazi was substantial during drought conditions beginning in 1993 .

The Lake Mzingazi example demonstrates how groundwater models can be used to implement resource- directed measures when a proper conceptualization (e.g., a two- versus one-layer 
model) is made and a detailed calibration performed (in this case, steady-state and transient aquifer heads and transient lake levels).

\section{Groundwater discharge to streams and water quality}

The focus of most investigation of groundwater/surface- water interaction in South Africa is on maintaining the desired streamflow to preserve the integrity of aquatic ecosystems. However, NWA measures to protect water resources are also aimed at preserving good water quality. Sometimes the focus is on contamination of groundwater from surface-water contaminants like bacteria or protozoa in areas of induced infiltration. The reverse was the subject of study for the Koekemoerspruit River in the North West Province of South Africa (Fig. 3). The area is one of intensive gold mining. Winde et al. (2004) investigated the fate and transport of dissolved uranium in groundwater emanating from slimes dams of the Buffelsfontein Gold Mine. The groundwater traveled through about $500 \mathrm{~m}$ of floodplain sediments before discharging to the Koekemoerspruit River. Uranium concentrations in groundwater in the alluvial sediments ranged from 0.24 to $0.54 \mathrm{mg} / \mathrm{L}$. Solid-phase concentrations in the sediments themselves were relatively low, averaging $28 \mathrm{mg} / \mathrm{kg}$ for wet soils. Concentrations were especially high, $1,192 \mathrm{mg} / \mathrm{kg}$, in salt crusts that had formed on slightly higher elevation surface sediments as a result of evaporation. Upon entering the hyporheic zone, however, uranium was largely removed from solution. Winde et al. (2004) hypothesized that the removal was due to coprecipitation of uranium; the uranium was incorporated into the matrix of precipitating oxyhydrates. This case study exemplifies how the hyporheic zone can act as a barrier to contamination. In this case, it was the transition zone between reducing conditions in ground- water and oxidizing conditions in stream water, thereby forming a barrier that protected the stream water from uranium contamination.

\section{Use of groundwater-vegetation relationships}

Vegetation and groundwater are affected by each other in ways that help assess the nature and spatial variability of groundwater discharge areas. These interactions in natural processes in South Africa were reviewed by Le Maitre et al. $(1999,2000)$. Most vegetation extracts water from the vadose zone, thereby reducing the amount of groundwater recharge. Transpiration can account for $5-100 \%$ of the annual rainfall, but generally ranges from 45 to $80 \%$. For example, in a case study in the Thabazimbi district of South Africa, the clearing of trees and shrubs resulted in a 20-m rise in the water table over 30 years (Le Maitre et al. 1999). Of course, reduced recharge results in decreased discharge at down-gradient surface-water bodies. Additionally, phreatophytes extract water directly from the saturated zone, thus further reducing groundwater discharge to streams. Root depths can extend quite far: about $7 \mathrm{~m}$ for trees, $5 \mathrm{~m}$ for shrubs and some legume, savannah trees reaching as far as $20 \mathrm{~m}$ and even $>53 \mathrm{~m}$ in one case. Eucalypts are grown on many South African plantations and typically extract water from $8 \mathrm{~m}$ in depth and in one case up to $60 \mathrm{~m}$. Phreatophytes, in turn, are especially sensitive to water-table fluctuations. Pumping of ground- water and aquifer depletion can lead to tree mortality and general damage to terrestrial, riparian and wetland plant communities (Le Maitre et al. 1999). 
Vegetation may be wholly or partly dependent on groundwater discharge, even in riparian zones where there is available surface water. Because groundwater often carries a higher nutrient load than does surface water, groundwater discharge can influence the plant types and numbers in the riparian zone. Groundwater/surface-water mixing zones, like the hyporheic zone, can be especially productive with the combination of nutrients and higher dissolved-oxygen content from surface water. Animal communities can also be more diverse and dense where there is groundwater upwelling into a surface-water body (Le Maitre et al. 1999). Vegetation patterns and species assemblages, therefore, are potential tools for investigating where groundwater discharge is occurring.

The effects of changing land-use and vegetative patterns on groundwater discharge were investigated in the Lake St. Lucia region (Fig. 3; Rawlins and Kelbe 1998). Specifically Rawlins and Kelbe examined the effects of commercial afforestation on the rates of ground- water discharge to the lake. The investigation was based on use of a three-dimensional numerical model of the system incorporating the local geology and vegetative types. Each vegetation type (indigenous trees, grassland and scrub, swamp and marshland and plantation trees) was assigned a representative rate of evapotranspiration. Groundwater recharge rates were based on observed water-table responses to precipitation events. Modeling results quantified the reduction in both surface-water flow and groundwater discharge to surface water with area afforestation since 1961. Total simulated groundwater discharge decreased 32 and $24 \%$ on the eastern and western shores of St. Lucia, respectively, due to the development of plantations. Rawlins and Kelbe (1998) hypothesized that such reductions would be most noticeable during periods of low rainfall and that during periods of high rainfall, the reductions would not be substantially detrimental to the lake's ecology.

\section{Approaches that are underutilized in South Africa}

Reviewers (Seward et al. 2006; Xu et al. 2008) have suggested that estimating groundwater discharge rates on a regional scale is not an acceptable approach towards implementing the NWA. Instead, through a process of public participation, specific discrete locations should be selected for an adaptive management approach. This section discusses methods that are more appropriate for characterizing and quantifying groundwater/surface-water interaction on a more site-specific scale. These methods (also summarized in Table 1) have been used in previous studies, but not widely in South Africa. To be most useful in South Africa, it is important that such methods can be practically applied in fractured-rock settings.

\section{Small-scale and hydrometric measurements}

There are methods that are widely used to measure groundwater exchange with surface water at discrete points within streams, rivers and lakes. Seepage meters, for example, allow direct measurement of the seepage flux between a surface-water body and the underlying groundwater system (Lee and Cherry 1978). Seepage meters comprise an inverted bucket imbedded into a streambed or lakebed. A bag with a known initial volume of water is attached to the 
bucket and will either gain or lose water at a rate controlled by the flux into or out of the bucket. Seepage meters have measured the flux between ground- water and streams (e.g., Cey et al. 1998) and lakes (e.g., Woessner and Sullivan 1984; Shaw and Prepas 1990). When using seepage meters in streams, care must be taken to protect the bags from head loss due to flowing water over the bags (Murdoch and Kelly 2003; Libelo and MacIntyre 1994; Levy et al. 2011).

Seepage meters are often used in conjunction with minipiezometers which are an easy way to measure the gradient direction and whether the surface-water body is gaining or losing water to the groundwater system in that area. Minipiezometers can also be used to perform slug tests to measure the hydraulic conductivity of material just below the streambed. This hydraulic conductivity can then be used in conjunction with hydraulic gradients and Darcy's law to calculate the groundwater flux (e.g., Cey et al. 1998).

Monitoring wells placed into a riverbed or lakebed and the nature of the temporal variability of temperature in the subsurface below a riverbed can be used to identify gaining and losing reaches of the surface-water body (Anderson 2005). In gaining reaches, the surface water will undergo seasonal and diurnal fluctuations in temperature reflecting the air temperature while the groundwater will maintain a relatively steady temperature. Subsurface temperatures might undergo slight diurnal fluctuations due to heat conduction from the surface-water body, but the fluctuations will be greatly dampened (Winter et al. 1998). In a losing reach, subsurface temperatures are affected by both heat conduction and advection and therefore demonstrate a greater response to the diurnal temperature fluctuations. This technique has been successfully applied in both humid and arid climates. (e.g., Conant 2004; Constantz et al. 2003a, b; Silliman and Booth 1993). Modeling the heat flow can allow quantification of the processes through model calibration in which temperature variations over time in the subsurface and surface water are used to estimate rates of groundwater discharge/ recharge as well as the hydraulic conductivity of the riverbed. Anderson (2005) reviewed the theory and application of such modeling efforts in a wide variety of settings. Many model codes are available for such simulations including the public-domain codes HST3D (Kipp 1997) and VS2DH (Healy and Ronan 1996).

At a somewhat larger scale, groundwater flux into or out of a stream can be inferred by measuring stream- flow at an upstream and downstream point. Streamflow can be measured using a current meter or with a tracer injection in the stream (Oxtobee and Novakowski 2002). Care must be taken to account for all other water fluxes into or out of the stream along the studied stretch (overland flow, tributaries, storm-sewer and tile- drain outfalls, etc.). Assuming no other fluxes, the difference in stream discharge between the upstream and downstream points yields the gain or loss from groundwater (e.g., Cey et al. 1998). In the context of groundwater management, this approach can be especially useful as the results before and after pumping can be directly applied to the assessment of groundwater extraction on streamflow (e.g., Myette et al. 1987). While point measurements of groundwater discharge may not be efficient methods for basin-scale management, they can be useful in fractured rock 
settings once areas of concentrated groundwater discharge have been identified as in methods described in the following.

\section{Vegetation-groundwater relationships in conjunction with groundwater modeling}

The relationship between phreatophytes and groundwater discharge is especially clear in arid and semi-arid regions (Batelaan et al. 2003). The relationship is less clear in humid areas and researchers have suggested that vegetative patterns should only be used with caution to delineate groundwater discharge areas or only as a rapid assessment and survey.

One example of an in-depth use of phreatophyte mapping for groundwater discharge assessment was that applied in the Grote-Nete basin in Belgium by Batelaan et al. (2003). This example could be important to applications in South Africa considering the appropriateness of vegetative mapping in semi-arid climates with discrete locations of groundwater discharge as in fractured-rock settings.

The study by Batelaan et al. (2003) indicates the usefulness of phreatophyte mapping to delineate ground- water discharge areas and groundwater flow modeling to delineate the contribution areas for those areas. Such methods could be valuable in South Africa for helping to determine the groundwater reserve and especially for identifying sensitive areas and for setting resource quality objectives that deal with where excessive groundwater extraction should be avoided. The modeling approach is especially useful for defining areas of protection and for estimating ecologically acceptable rates of groundwater extraction based on the effects on the groundwater discharge and ultimately on the extent and abundance of the vegetation. In the case of fractured-rock settings in South Africa, the vegetative mapping could be especially useful; however, the modeling is much less straightforward. Without detailed characterization of fracture zones or even individual fractures, the delineation of contribution zones to discharge areas will likely not be reliable.

\section{Use of geochemistry and temperature}

Evaluation of the impact of a proposed production well on aquatic ecosystem health can be improved by identifying the areas of concentrated groundwater discharge in streams (especially in fractured-bedrock environments), and if possible, quantifying the groundwater contributions. Such areas have been identified based on changes in water temperature and electrical conductivity along the length of the stream. The technique depends on clear differences between surface water and groundwater temperature and geochemistry. Groundwater is often higher in electrical conductivity and maintains a stable temperature throughout the year relative to surface water. Zondlo (1998), for example, applied this technique to find areas of ground- water discharge near Oak Ridge, Tennessee, USA, although the method had several limitations. It only worked well where surface-water flow rates were negligible and where the stream was in direct contact with the fractured bedrock. Where there 
were thick deposits of sediments between the stream bottom and the bedrock, groundwater discharge was diffuse.

Allen et al. (2010) took a geochemical approach in combination with hydraulic head data towards investigating groundwater interaction with the River Lambourn near Boxford, England (UK). It was known that the river gained or lost water in discrete sections due to the fracture system in the underlying Chalk formation. Major anions and cations concentration differences between the Chalk aquifer, the river and an intervening gravel indicated that there was limited interaction between the Chalk and the gravel, and complex exchanges between the river and gravel. Allen et al. (2010) inferred that the gravel dispersed the potentially discrete discharge of water from the Chalk.

Genereux and Jordon (2006) used river and aquifer geochemistry and stable isotopes (discussed in the following) to characterize the importance of interbasin groundwater flow (IGF) near the La Selva Biological Station in the Cordillera Central of Costa Rica. Determination of IGF has potentially great importance to ground- water and surface-water management. Groundwater studies often begin with the assumption that groundwater divides correspond to the overlying surface-water divides, and these boundaries are then used as part of the determination of the impact on surface water by ground- water development. If, on the other hand, groundwater actually flows between surface-water basins, then ground- water development might have minimal impacts in the targeted basin but have greater than expected impacts in an adjacent basin. Within the Costa Rican field area, high concentrations of major ions in groundwater were associated with volcanic-fluid interactions from Volcan Barva, about $30 \mathrm{~km}$ south and outside the surface-water basin of La Selva. Groundwater at La Selva had this high- concentration signature indicating the groundwater had flowed there via IGF. The spatial variation of ion concentrations in area streams was explained by mixing of relatively low-ion-concentration local water from precipitation and high-concentration IGF groundwater. Using mixing calculations, Genereux and Jordon (2006) concluded that about two-thirds of the annual inputs to the local stream at La Selva were from IGF. A stream in an adjacent basin that did not receive IGF only had about one-quarter of the flow. Clearly, estimations of the groundwater reserve in South Africa would be enhanced by being able to determine the relative contributions to streams from groundwater emanating from different aquifers and areas.

Praamsma and Novakowski (2006) explored ground- water discharge to a 1.2-km stretch of the Tay River in a fractured gneiss terrain near Perth, ON, Canada. Electrical conductivity and stable isotope concentrations (discussed in the following) in samples from multilevel piezometers were used to determine that groundwater discharge was minimal in the study area. Oxtobee and Novakowski (2002) also used stream and aquifer temperatures and electrical conductivity in Smithville, ON, Canada, to delineate and quantify groundwater discharge rates to Twenty Mile Creek and one of its tributaries, North Creek, mainly through a network of large horizontal bedrock fractures. The methodology was employed in combination 
with stable isotopic analyses (discussed in the following), seepage meters, head gradients measured in minipiezom- eters and streamflow measurements. A continuous electrical conductivity survey in the creek along the length of the study area revealed four discrete zones of groundwater discharge in Twenty Mile Creek (as indicated by increased electrical conductivity and decreased temperature) and one in North Creek. Results agreed with isotopic analyses. Using the electrical conductivity contrasts, the amount of groundwater discharge was quantified at discrete locations using a simple two-component mixing model.

Turner and Townley (2006) used chloride concentrations to identify the zone of lake-water discharge to the underlying aquifer for lakes in the Swan Coastal Plain of southwestern Australia. Analyses were based on the fact that there was both isotopic (see the following) and chemical enrichment in lake water due to evaporation relative to the groundwater flowing into and beneath the lakes. Using an array of multi-level piezometers beneath and downgradient of the lakes, zones of lake-water loss to the aquifer could be clearly identified. Turner and Townley (2006) used their results to improve numerical modeling of flow through the groundwater-lake system, allowing better estimations of groundwater inputs and discharge zones to the lakes as well. They maintained that such an approach can aid decision-making regarding land and groundwater use.

\section{Use of stable Isotopes ${ }^{18} \mathrm{O}$ and ${ }^{2} \mathrm{H}$}

One tool that has been increasingly used to augment investigations of groundwater/surface-water interactions has been analysis of stable isotopes of oxygen and hydrogen. Although stable isotope analysis has not been widely used in the context of applying South African water policy, like geochemical approaches, it has great potential for delineating groundwater discharge areas and even for quantification of groundwater discharge in any kind of geologic setting including fractured bedrock aquifers. Deuterium and ${ }^{18} \mathrm{O}$ have been used to locate and confirm groundwater discharge locations (e.g., Oxto- bee and Novakowski 2002), quantify groundwater discharge to surface water (e.g. Space et al. 1991), confirm the recharge of groundwater systems from surface-water impoundments (e.g., Lawson et al. 2008) identify sources of water in municipal wells (e.g., Hunt et al. 2005), distinguish the sources of groundwater recharge (e.g., Blasch and Bryson 2007; Criss and Davisson 1996) and aid in the investigation of arsenic contamination of groundwater mediated by surface-water and irrigation- water infiltration into groundwater systems (Lawson et al. 2008).

Isotopic methods are often used in conjunction with geochemical analyses (Genereux and Jordon 2006; Praamsma and Novakowski 2006; Turner and Townley 2006). In the case of the Costa Rican study by Genereux and Jordon (2006), depleted ${ }^{18} \mathrm{O}$ concentrations in groundwater discharging to a low-elevation stream indicated their source was precipitation at high elevation. This interpretation supported the geochemical analyses indicating IGF from a high-elevation volcanic area. In the River Dee basin in Scotland, UK, river geochemistry and ${ }^{18} \mathrm{O}$ concentrations indicated the often-overlooked importance of groundwater sources in the montane headwaters relative to the downsteam baseflows (Tetzlaff and Soulsby 2008). 
In settings where the stream flows directly on the fractured bedrock, groundwater discharge to streams may occur only in discrete locations associated with individual fractures (Oxtobee and Novakowski 2002). In such settings, stable isotopes can be used to help locate discharge points. Such information is useful for proper siting of boreholes to protect ecologically sensitive areas. Oxtobee and Novakowski (2002) used ${ }^{2} \mathrm{H}$ and ${ }^{18} \mathrm{O}$ concentrations in water samples in conjunction with many other methods (as described previously) to investigate and quantify exchanges between surface water and a fractured- bedrock aquifer along a 5 -km stretch of Twenty Mile Creek near Smithville, ON, Canada. Precipitation samples were collected during seven storm events over a 10-month period to develop a local meteoric water line. Samples were also taken in two shallow piezometers to establish the isotopic signature for shallow groundwater. Creek water samples were collected in an area believed to be void of groundwater discharge to represent the surface- water isotopic signature. Precipitation and surface-water samples were relatively enriched in ${ }^{2} \mathrm{H}$ and ${ }^{18} \mathrm{O}$ during the summer months. Surface water was enriched compared with precipitation and groundwater, especially in mid to late summer when the creek actually became disconnected and evaporation had its greatest effect. Electrical conductivity, temperature surveys (described previously) and fracture observations of the creek revealed five points of potential groundwater discharge, and these points were sampled for isotopic analysis. The ${ }^{2} \mathrm{H}$ and ${ }^{1} \mathrm{O}$ analyses indicated the water in these areas was consistent with groundwater, confirming the influence of groundwater discharge in these areas. This analysis was only effective in summer due to the similarity of winter-time ${ }^{2} \mathrm{H}$ and ${ }^{18} \mathrm{O}$ concentrations in surface water and groundwater.

Turner and Townley (2006) also used stable isotopes to delineate the area in an aquifer that was receiving water from lakes on the Swan Coastal Plain of western Australia based on the fact that isotopic enrichment was occurring in the lakes due to evaporation. Along with chloride concentrations (as described previously) the analyses allowed validation of numerical models that could enhance groundwater and land management.

Depending on the setting and use, geochemical and isotopic methods have advantages and disadvantages. For Turner and Townley (2006) using chloride concentrations had the advantage over stable isotopes in that there was no upper limit chloride enrichment due to evaporation. Enrichment of stable isotopes by evaporation, however, was limited by exchange processes across the air-water interface. On the other hand, unlike the stable isotopes, chloride could be enriched in the groundwater system due to transpiration from shallow water tables. Genereux and Jordan found that mixing calculations based on chloride had lower uncertainties relative to ${ }^{18} \mathrm{O}$ due to less variability in the end-member chloride concentrations. Still, ${ }^{18} \mathrm{O}$ provided excellent corroboration of the IGF implications from ion analaysis.

\section{Conclusions and recommendations}

Groundwater and surface water are resources that should not be studied, observed or managed separately. Not only are they closely connected, but through groundwater flow, different 
surface waters, streams, wetlands and dry land areas also connect with each other. The lack of understanding of the interactions is a hindrance to effective, responsible and sustainable management of water resources and should thus be addressed urgently. As processes are never fully known, it is difficult to propose effective management scenarios to prevent damage to water resources and ecosystems while also providing for speedy social and economic development. Historically, management systems around the world have not been adequate to achieve this balance. Nelson Mandela once said, "It is one thing to find fault with an existing system. It is another thing altogether, a more difficult task, to replace it with an approach that is better (Postel and Richter 2003)." South Africa's 1998 NWA aims to balance ecological protection and economic development and represents an approach as holistic and progressive as any in the world. In fact, the NWA may "come to be seen by future water historians as a major turning point in world water affairs" (Postel and Richter 2003). The European Union's Water Framework Directive of 2000, for example, included a classification system for the ecological status of aquatic systems, much like South Africa's system. Australia has also adopted a system of determining acceptable environmental flows similar to South Africa's.

Ecological protection is written into the NWA as well as the 1996 South African Constitution, but ecological protection is clearly meant to be for the social and economic wellbeing of South African citizens. The concept of the Reserve (the preservation of water to meet basic human needs and to ensure ecological integrity) is not for improving or preserving ecosystems for their own sake at the expense of the economic and social welfare of South Africans. Rather it is to protect aquatic systems so that all people of all races and socio-economic backgrounds can benefit from water resources and both in- stream and out-of-stream uses.

Estimating the Reserve of a groundwater resource requires first allotting $25 \mathrm{~L} /$ day per person potentially served by the resource. Calculating the amount of groundwater required to preserve or improve ecological integrity is more challenging. The first step usually entails gaining an understanding of the contribution of ground- water to aquatic ecosystems under pre-development conditions. In this process of increasing understanding, conceptualization and quantification of rates of ground- water to surface water are equally important.

In practice, the study of interactions is not straightforward in South Africa. Most areas have had a historic focus on either ground- or surface-water monitoring, which makes studies of exchanges very difficult. The situation is further complicated because the majority of available groundwater resources in South Africa comes from fractured-bedrock aquifers. This geologic setting is subject to great spatial heterogeneity and anisotropy of aquifer characteristics and groundwater discharge to surface-water bodies. The most common approach in South Africa for implementation of the NWA has been estimation of average annual flux rates at the regional scale of quaternary catchments and then applying a water-balance approach, subtracting the groundwater discharge rate from the recharge rate. Groundwater discharge is most often estimated with baseflow separation techniques. This water-balance approach might be a good first step, but it ignores spatial and temporal variability. Baseflow separation techniques are 
certainly informative and can provide estimates of the total groundwater contribution to a stream; but when applied to a single downstream hydro- graph, they do not account for spatial heterogeneity and, therefore, ignore the potential impacts associated with placement of production boreholes.

On a more local scale, a Darcy's law approach has the potential to incorporate more heterogeneity depending on the spatial coverage of available water-level and aquiferparameter data. With a good coverage, hydraulic head gradients can be calculated with groundwater mapping, and these gradients can be used along with estimates of aquifer transmissivity or hydraulic conductivity to calculate the rates of groundwater discharge. The accuracy of the estimates will depend on the extent and quality of the available data. On an even smaller scale, seepage meters and heat-flow modeling can quantify groundwater fluxes to and from surface water. While such point measurements may not be useful for watershed-scale water management they can be helpful in understanding the hydrology of particularly sensitive or important areas.

To deal directly with the issue of identifying discrete areas of groundwater discharge, stable-isotopic and geo- chemical analyses can be used based on the different isotopic and geochemical signatures of precipitation, groundwater and surface water. For precipitation, isotopic signatures depend on many factors, thereby necessitating the development of a local meteoric water line. Differences between groundwater and surface water mainly depend on the degree of evaporation that has occurred from the system since the precipitation occurred. Geochemical differences between groundwater and surface water also result from the long contact times of ground- water with aquifer media. Sampling an array of ground- water, surface-water and precipitation monitoring stations within a basin can lead to an increased understanding of the flow system including a delineation of the principal groundwater discharge areas.

Eventually, data availability will determine what kind of quantification is possible on which scale. If possible, it is best to combine several estimation methods in order to prevent large-scale errors. Vegetative mapping can be a useful tool in combination with other methods to identify probable groundwater-discharge areas and ecologically important zones. Whichever other method is employed, groundwater flow modeling is a powerful tool that incorporates a holistic use of available data and, most important, has the ability to make predictions of the impacts of groundwater extraction and development in spatially heterogeneous environments.

The NWA calls for the estimation of the Reserve before licensed development can occur. Groundwater development will always affect the flow system and will always change groundwater discharge rates. As suggested by Seward et al. (2006), the best that can be done is not to find a safe yield, but an optimal yield, one that recognizes the trade-offs between preservation and development. Given the difficulty in estimating the Reserve and designing a development scheme to preserve it (through resource quality objectives), South Africa faces a situation in which the allocation of groundwater for economic development is a very slow 
process. The Department of Water Affairs may be understandably reluctant to grant licenses for groundwater extraction when there is so much scientific uncertainty associated with Reserve estimation and preservation. Reduction of uncertainty requires the terribly time-consuming process of more data collection and application of more sophisticated methods to understand and quantify groundwater fluxes and predict the impacts of human intervention. Such sophisticated approaches and combinations of methods may not be economically or scientifically practical in all or even in most cases. The current situation has led some in the groundwater industry to joke that the NWA is so good that it is impossible to implement. As suggested by Xu et al. (2008) and Seward et al. (2006), the economic and human-resource constraints necessitate the application of adaptive management approach applied to discrete locations chosen based on their social, economic and ecological importance. In this approach, the allocation of groundwater for uses beyond the Reserve needs to be an iterative process in which smaller areas are studied in greater detail and all allocations are considered experimental. The estimated effects of development scenarios are considered to be hypotheses that are tested with continued monitoring of water levels, groundwater fluxes and ecosystem health. Management objectives are regularly revisited and revised and alternative strategies are considered. Adaptive management might entail pilot-scale abstractions before large-scale development can occur (Seward et al. 2006). It is clear that adaptive management requires increased development of groundwater-monitor- ing systems. Such systems will always be useful, not only with respect to application of the methods outlined here, but also in the development of a proper conceptual model of the system in question, probably the most important step in any investigation of groundwater/surface-water interaction.

\section{Acknowledgements}

We would like to thank the Fulbright US Scholar Program within the US Department of State and the Bureau of Educational and Cultural Affairs for providing the opportunity for the extended collaboration of the authors. Partial support by VLIR (the Flemish Interuniversity Council and NUFU (the Norwegian Programme for Development, Research and Education) projects granted to the UNESCO Chair in Hydrogeology is sincerely acknowledged. Thanks also to Naomi Levy for her valuable editing.

\section{References}

Allen DJ, Darling WG, Gooddy DC, Lapworth DJ, Newell AJ, Williams AT, Allen D, Abesser C (2010) Interaction between groundwater, the hyporheic zone and a Chalk stream: a case study from the River Lambourn, UK. Hydrogeol J 18:1125-1141 
Alley WM, Reilly TE, Franke OL (1999) Sustainability of groundwater resources. US Geol Surv Circ 1186, $79 \mathrm{pp}$

Anderson MP (2005) Heat as a ground water tracer. Ground Water 43(6):951-968

Batelaan O, De Smedt F, Triest L (2003) Regional groundwater discharge: phreatophyte mapping, groundwater modeling and impact analysis of land-use change. J Hydrol 275(1-2):86-108

Blasch KW, Bryson JR (2007) Distinguishing sources of ground water recharge by using $\mathrm{S}^{2} \mathrm{H}$ and $\mathrm{S}^{18} \mathrm{O}$. Ground Water 45 (3):294-308

Cey EE, Rudolph DL, Parkin GW, Aravena R (1998) Quantifying groundwater discharge to a small perennial stream in southern Ontario, Canada. J Hydrol 210:21-37

Conant BJ (2004) Delineating and quantifying ground water discharge zones using streambed temperatures. Ground Water 42(2):243-257

Constantz J, Cox MH, Sarma L, Mendez G (2003a) The Santa Clara River: the last natural river of Los Angeles. In: Stonestrom DA, Constantz J (eds) Heat as a tool for studying the movement of ground water near streams. US Geol Surv Circ 126o, pp 21-27

Constantz J, Cox MH, Su GW (2003b) Comparison of heat and bromide as ground water tracers near streams. Ground Water 41 (5):647-656

Criss RE, Davisson ML (1996) Isotopic imaging of surface water/ groundwater interactions, Sacramento Valley, California. J Hydrol 178:205-222

de Vries, JJ (2000) Groundwater level fluctuations: the pulse of the aquifer. Paper presented at "Evaluation and Protection of Groundwater Resources" Conference, Wageningen, The Netherlands, 16 pp

Dennis I (2008) Groundwater Reserve Determination for the Thukela Catchment. Inception report, Project number WP9437/3. Department of Water Affairs and Forestry, Pretoria, South Africa

DWAF (1997) White paper on a national water policy for South Africa. Department of Water Affairs and Forestry, Pretoria, South Africa

DWAF (2003) Resource directed measures, module 1: introductory module. Department of Water Affairs and Forestry, Pretoria, South Africa 
DWAF (2004) National water resource strategy, 1st edn. Department of Water Affairs and Forestry, Pretoria, South Africa

DWAF (2005) Groundwater resource assessment, phase II: methodology. Groundwater-surface water interactions. Department of Water Affairs and Forestry, Pretoria, South Africa Funke N, Nortje K, Findlater K, Burns M, Turton A, Weaver A, Hattingh H (2007) Redressing inequality, South Africa's new water policy. Environment 49(3):10-23

Gardner KM (1999) The importance of surface water/ground- water interactions. Environmental Protection Agency, Seattle, WA, 18 pp

Genereux DP, Jordon M (2006) Interbasin groundwater flow and groundwater interaction with surface water in a lowland rainforest, Costa Rica: a review. J Hydrol 320:385-399

Hancock PJ, Boulton AJ, Humphreys WF (2005) Aquifers and hyporheic zones: towards an ecological understanding of groundwater. Hydrogeol J 13:98-111

Harris J, van Vliet HR, MacKay HM (1999) Water resource quality policy: the approach adopted by the Department of Water Affairs and Forestry under the Water Law principles. Water Sci Technol 29(10-11):31-37

Healy RW, Ronan AD (1996) Documentation of computerprogram VS2DH for simulation of energy transport invariably saturated porous media: modification of the U.S. Geological Survey's computer program VS2DT. US Geol Surv Water Resour Invest Rep 4230

Herold CE (1980) A model to compute on a monthly basis diffuse salt loads associated with runoff. WRCPWVS project, HRU Report No. 1/80, University of the Witwatersrand, Witwatersrand, South Africa

Hughes DA, Hannart P, Watkins D (2003) Continuous baseflow separation from time series of daily and monthly streamflow data. Water SA 29(1):43-48

Hunt RJ, Coplen TB, Haas NL, Saad DA, Borchardt MA (2005) Investigating surface water-well interaction using stable isotope ratios of water. J Hydrol 302:154-172

Hunt RJ, Strand M, Walder JF (2006) Measuring groundwater- surface water interaction and its effect on wetland stream benthic productivity, Trout Lake watershed, northern Wisconsin, USA. J Hydrol 320:370-384

Kelbe BE, Germishuyse T (2000) The interaction between coastal lakes and the surrounding 
aquifer. In: Sililo et al (eds) Groundwater: past achievements and future challenges. Balkema, Dordrecht, The Netherlands

Kipp KL Jr (1997) Guide to the revised heat and solute transport simulator: HST3D. US Geol Surv Water Resour Invest Rep 97-4157

Klemes V (1983) Conceptualisation and scale in hydrology. In: Rodriguez-Iturbe I, Gupta VK (eds) Scale problems in hydrology. J Hydrol 65:1-23

Lawson M, Ballentine CJ, Polya DA, Boyce AJ, Mondal D, Chatterjee D, Majumder S, Biswas A (2008) The geochemical and isotopic composition of ground waters in West Bengal: tracing ground-surface water interaction and its role in arsenic release. Mineral Mag 72(1):441-444

Le Maitre DC, Colvin C (2008) Assessment of the contribution of groundwater discharges to rivers using monthly flow statistics and flow seasonality. Water South Africa 34 (5):549-564

Le Maitre DC, Scott DF, Colvin C (1999) A review of information on interactions between vegetation and groundwater. Water South Africa 25(2):137-152

Le Maitre DC, Scott DF, Colvin C (2000) Information on interactions between groundwater and vegetation relevant to South African conditions: a review. In: Sililo et al (eds) Groundwater: past achievements and future challenges. Balkema, Dordrecht, The Netherlands

Lee DR, Cherry JA (1978) A field exercise on groundwater flow using seepage meters and mini-piezometers. J Geol Edu 27:6-10

Levy J, Birck MD, Mutiti S, Kilroy KC, Windeler B, Idris O, Allen LN (2011) The impact of storm events on a riverbed system and its hydraulic conductivity at a site of induced infiltration. J Environ Manage 92:1960-1971

Libelo EL, MacIntyre WG (1994) Effects of surface-water movement on seepage-meter measurements of flow through the sediment-water interface. Appl Hydrogeol 4:49-54

MacKay H (2000) Moving towards sustainability: the ecological Reserve and its role in implementation of South Africa's water policy. Proc. of the World Bank Water Week Conf., Washington. DC, April 2000

McCarthy TS (2006) Groundwater in the wetlands of the Okavango Delta, Botswana, and its contribution to the structure and function of the ecosystem. J Hydrol 320:264-282

McCartney MP, Acreman MC, Bergkamp G (2000) Freshwater ecosystem management and 
environmental security. Background paper to Vision for Water and Nature Workshop, San \ Jose (Costa Rica), 20-22 June 1999, IUCN, Gland, Switzerland

McDonald MG, Harbaugh AW (1988) A modular three-dimensional finite-difference ground-water flow model. Techniques of Water-Resources Investigations, Book 6, Chapt. A1. US Geological Survey, Reston, VA

McKune C (2009) South Africa water reserves are declining - study. IOL on-line news, www.iol.co.za/SAwaterprobs-news. htm.. Cited May 2010

Midgley DC, Pitman WV, Middleton BJ (1994) The surface water resources of South Africa 1990, Vols 1-6. report nos. 298/1.1/ 94-298/6.1/94, Water Research Commission, Pretoria, South Africa

Murdoch LC, Kelly SE (2003) Factors affecting the performance of conventional seepage meters. Water Resour Res 39(6):1-10. doi: 10.1029/2002WRo01347

Myette CF, Johnson DG, Olimpio JC (1987) Area of influence and zone of contribution to superfund site wells G and H, Woburn, Massachusetts. US Geol Surv Water Resour Invest Rep 874100, 86 pp

Nathan RJ, McMahon TA (1990) Evaluation of automated techniques for base flow and recession analyses. Water Resour Res 26(7):1465-1473

Oxtobee JPA, Novakowski K (2002) A field investigation of groundwater/surface water interaction in a fractured bedrock environment. J Hydrol 269:169-193

Parsons R (2009a) Is Groenvlei really fed by groundwater discharged from the Table Mountain Group (TMG) aquifer? Water SA 35(5):657-662

Parsons R (2009b) Quantifying groundwater's role in sustaining Groenvlei, a shallow lake in the Southern Cape Region of South Africa. International Association of Hydrological Sciences Publication 320. IAHS, Wallingford, UK

Parsons R, Wentzel J (2007) Groundwater resource directed measures manual. WRC report no. TT 299/o7. Water Resources Commission, Pretoria, South Africa

Poff NL, Allan JD, Bain MB, Karr JR, Prestegaard KL, Richter BD, Sparks RE, Stromberg JC (1997) The natural flow regime: a paradigm for river conservation and restoration. Bioscience 47:769-784

Postel S, Richter B (2003) Rivers for life. Island Press, Washington, DC, 253 pp 
Praamsma TW, Novakowski K (2006) Using $\mathrm{S} 18 \mathrm{O}$ and $\mathrm{SD}$ to investigate complex groundwater-surface water interaction and recharge in a gneissic terrain, Perth, Ontario. Geol Soc Am Abstr 38(7):232

Rawlins BK, Kelbe BE (1998) Groundwater modelling of the impact of commercial forestry on an ecologically sensitive coastal lake. Hydrology in a Changing Environment: Proceeding of the British Hydrological Society International Conference, Exeter, UK, July, 1998

Republic of South Africa (RSA) (1998) National Water Act No. 36 of 1998. Government Printer, Pretoria, South Africa

Republic of South Africa (RSA) (1997) Water Services Act No. 108 of 1997, Government Printer, Pretoria, South Africa

Roberts J (2010) South Africa water demand 'will exceed supply by 2025'. Mail Guardian Online,http://mg.co.za/article/2010-02-04-sa- water-demand-will-exceed-supply-by-2025. Cited 7 February 2010

Roets W, Xu Y, Raitt L, Brendonck L (2008a) Groundwater discharges to aquatic ecosystems associated with the Table Mountain Group (TMG) aquifer: a conceptual model. Water SA 34(1):77-88

Roets W, Xu Y, Raitt L, El-Kahloun M, Meire P, Calitz F, Batelaan O, Anibas C, Paridaens K, Vandenbroucke T, Verhoest NEC, Brendonck L (2008b) Determining discharges from the Table Mountain Group (TMG) aquifer to wetlands in the Southern Cape. Hydrobiologia 607:175-186

SA-Venues.com (2001) South Africa weather and climate. http:// www.sa-venues.com/no/weather.htm. Cited 14 July 2011

Schreiner B, van Koppen B (2003) Policy and law for addressing poverty, race and gender in the water sector: the case of South Africa. Water Policy 5:489-501

Schulze RE, Maharaj M, Lynch SD, Howe BJ, Melvil-Thompson B (1997) South African atlas of agrohydrology and climatology. WRC report, TT82/96, ACRU report 46, Water Research Commission, Pretoria, South Africa, $276 \mathrm{pp}$

Seward P (2010) Challenges facing environmentally sustainable ground water use in South Africa. Ground Water 48(2):239-245

Seward P, Xu Y, Brendonck L (2006) Sustainable groundwater use, the capture principle and 
adaptive management. Water SA $32(4): 473-482$

Shaw RD, Prepas EE (1990) Groundwater-lake interactions: I, accuracy of seepage meter estimates of lake seepage. J Hydrol 119:105-120

Shedlock RJ, Wilcox DA, Thompson TA, Cohen DA (1993) Interactions between ground water and wetlands, southern shore of Lake Michigan, USA. J Hydrol 141:127-155

Silliman SE, Booth DF (1993) Analysis of time-series measurements of sediment temperature for identification of gaining vs. losing portions of Juday Creek, Indiana. J Hydrol 146:131-148 Smakhtin VU (2001a) Low flow hydrology: a review. J Hydrol 240:147-186

Smakhtin VU (2001b) Estimating continuous monthly baseflow time series and their possible applications in the context of the ecological reserve. Water SA 27:213-217

Sophocleous M (2000) From safe yield to sustainable development of water resources: the Kansas experience. J Hydrol 235(1-2):27-43

Sophocleous M (2002) Interactions between groundwater and surface water: the state of the science. Hydrogeol J 10:52-67

Space ML, Ingraham NL, Hess JW (1991) The use of stable isotopes in quantifying groundwater discharge to a partially diverted creek. J Hydrol 129:175-193

Turner JV, Townley LR (2006) Determination of groundwater flow- through regimes of shallow lakes and wetlands from numerical analysis of stable isotope and chloride tracer distribution patterns. J Hydrol 320:451-483

Tetzlaff D, Soulsby C (2008) Sources of baseflow in larger catchments: using tracers to develop a holistic understanding of runoff generation. J Hydrol 359:287-302

van Wyk E, Breen CM, Roux DJ, Rogers KH, Sherwill T, van Wilgen BW (2006) The ecological reserve: towards a common understanding for river management in South Africa. Water SA 32(3):403-410

Vetger JR (1995) An explanation of a set of national groundwater maps. WRC report TT 74/95. Water Research Commission, Pretoria, South Africa

Winde F, Wade P, van der Walt IJ (2004) Gold tailings as a source of waterborne uranium contamination of streams: the Koeke- moerspruit (Klerksdorp goldfield, South Africa) as a case study. Part I of III: Uranium migration along the aqueous pathway. Water SA 30(2):219-225 
Winter TC, Harvey JW, Franke OL, Alley WM (1998) Groundwater and surface water, a single resource. US Geol Surv Circ 1139 Woessner WW, Sullivan KE (1984) Results of seepage meter and mini-piezometer study, Lake Mead, Nevada. Ground Water $22(5): 561-568$

Woodford A, Rosewarne P, Girman J (2005) How much ground- water does South Africa have? Report for the Groundwater Phase 2 Project, Department of Water Affairs and Forestry, Pretoria, South Africa. www.srk.co.uk/groundwater/PDFs/1_A_Woodford.pdf. Cited May 2010

Wright KA, Xu Y (2000) A water balance approach to the sustainable management of groundwater in South Africa. Water South Africa 26(2):167-170

Xu Y, Braune E, Colvin C, Le Maitre D, Pietersen K, Hatton T (2000) Comprehensive determination of the resource directed measures for groundwater. In: Sililo et al (eds) Groundwater: past achievements and future challenges. Balkema, Dordrecht, The Netherlands

Xu Y, Titus R, Holness SD, Zhang J, van Tonder GJ (2002) A hydromorphological approach to quantification of groundwater discharge to streams in South Africa. Water SA 28(4):375-380

Xu Y, Duah A, Kanyerere T, Seward P (2008) Review of the DWAF RDM report entitled "Groundwater Reserve Determination for the Thukela Catchment, Inception Report" by Ingrid Dennis. Project no. WP9437/3, Institute for Groundwater Studies, University of the Free State, Bloemfontein,South Africa

Zondlo F (1998) Identification of subaqueous groundwater discharge to large scale surface water bodies, East Tennessee Technology Park site, DOE Oak Ridge Reservation, Oak Ridge, Tennessee, MSc thesis, University of Tennessee at Knoxville, USA, 258 pp 